\title{
Stratigraphical, sedimentological and palaeofloristic characterization of the Sorocayense Group (Triassic) in Barreal depocenter, San Juan Province, Argentina
}

\author{
*Josefina Bodnar ${ }^{1,2}$, Ari Iglesias ${ }^{2,3}$, Carina E. Colombi ${ }^{2,4}$, Juan Martín Drovandi², \\ ${ }^{I}$ División Paleobotánica, Facultad de Ciencias Naturales y Museo, Universidad Nacional de La Plata. Paseo del Bosque s/n, B1900FWA \\ La Plata, Buenos Aires, Argentina \\ jbodnar@fcnym.unlp.edu.ar \\ ${ }^{2}$ Consejo Nacional de Investigaciones Cientificas y Técnicas (CONICET). \\ ${ }^{3}$ Instituto de Investigaciones en Biodiversidad y Medioambiente (INIBIOMA), Universidad Nacional del Comahue-CONICET. Quintral \\ 1250, R8400FRF San Carlos de Bariloche, Río Negro, Argentina \\ ari_iglesias@yahoo.com.ar \\ ${ }^{4}$ Instituto y Museo de Ciencias Naturales, Universidad Nacional de San Juan, Av. España 400 (norte), J5400DNQ San Juan, San \\ Juan, Argentina. \\ ccolombi@unsj.edu.ar;drovandijuan@gmail.com \\ *Corresponding autor: jbodnar@fcnym.unlp.edu.ar
}

\begin{abstract}
The northern area of Cuyo Basin (west-central Argentina) corresponds to the Rincón Blanco half-graben, whose filling is arranged into the Rincón Blanco and Sorocayense groups. In the present study, we propose a new stratigraphic scheme for the Sorocayense Group in the Barreal depocenter (San Juan Province), revise the palaeoenvironmental interpretations, and organize and analyse the plant assemblages of previous and new fossiliferous levels. We defined three tectosedimentary sequences. The basal sequence represents the initial graben filling with pyroclastic flows, alluvial fan, and ephemeral fluvial systems, and is arranged in a new unit, the Cerro Colorado del Cementerio Formation. The middle sequence, including Barreal and Cortaderita formations, is characterized by sediment gravity flow deposits and different fluvial systems, with development of floodplains with vertisols and calcisols, and temporal ponds/lakes. In turn, the Cortaderita Formation was divided into the following lithostratigraphic members: Don Raúl and La Emilia. The upper sequence, represented by Cepeda Formation, was deposited by distributary fluvial and ephemeral fluvial systems. Twelve fossiliferous strata $(\mathrm{EF})$ were recognized, which were all identified in the middle sequence: EF1 to EF3 in the Barreal Formation, EF4 to EF8 in the Don Raúl Member, and EF9 to EF12 in the La Emilia Member, both of Cortaderita Formation. The taphocoenosis found in the Barreal and Cortaderita formations were dominated by corystosperms, with conifers, cycadales, and peltasperms as subordinate forms. The available evidence from the taphofloras, palaeosols and palaeonvironments indicate the development of seasonal subtropical climates, which vary from arid or semi-arid in the basal sequence, sub-humid to semi-arid in the middle sequence, and arid or semi-arid in the upper sequence. On the basis of the new information, geological correlation and age of the lithostratigraphic units were accurately re-evaluated. Based on the palaeofloristic content and the correlation with the Rincón Blanco Group, it is possible to infer that the basal sequence was accumulated during late Early Triassic-early Middle Triassic, the middle sequence during the Middle Triassic, while the upper sequence was deposited in the early Late Triassic.
\end{abstract}


RESUMEN. Caracterización estratigráfica, sedimentológica y paleoflorística del Grupo Sorocayense (Triásico) en el área de Barreal, provincia de San Juan, Argentina. El área norte de la cuenca Cuyana (centro-oeste de la Argentina) corresponde al hemigraben de Rincón Blanco, cuyo relleno comprende los grupos Rincón Blanco y Sorocayense. En este estudio, se propone un nuevo esquema estratigráfico para el Grupo Sorocayense en el depocentro de Barreal, se reinterpretan los paleoambientes, y se organizan y analizan las asociaciones plantíferas de niveles fosilíferos nuevos y previamente estudiados. Se definieron tres secuencias tecto-sedimentarias. La secuencia basal representa el relleno inicial del hemigraben con depósitos de flujos piroclásticos, abanicos aluviales y sistemas fluviales efímeros, y es incluida en una nueva unidad: Formación Cerro Colorado del Cementerio. La secuencia media, que comprende a las formaciones Barreal y Cortaderita, se caracteriza por depósitos de flujos gravitacionales de sedimentos, y diferentes sistemas fluviales, con planicies de inundación en las que se desarrollaron vertisoles y calcisoles, y estanques o lagunas temporales. La Formación Cortaderita fue dividida en los siguientes miembros litoestratigráficos: Don Raúl y La Emilia. La secuencia superior, representada por la Formación Cepeda, fue depositada por sistemas fluviales distributarios y efímeros. Se reconocieron doce estratos fosilíferos (EF), todos identificados en la secuencia media: EF1 al EF3 en la Formación Barreal; EF4 al EF8 en el Miembro Don Raúl; y EF9 al EF12 en el Miembro La Emilia, ambos de la Formación Cortaderita. Las tafocenosis halladas están dominadas por corystospermas, con las coníferas, cycadales y peltaspermas como formas subordinadas. La evidencia disponible acerca de las tafofloras, paleosuelos y paleoambientes indican el desarrollo de climas subtropicales estacionales, que varían de áridos a semiáridos en la secuencia basal, subhúmedos a semiáridos en la secuencia media, y áridos o semiáridos en la secuencia superior. Con la nueva información, se reevaluaron las correlaciones y la edad de las unidades en forma más precisa. Sobre la base del contenido paleoflorístico y la correlación con el Grupo Rincón Blanco, se infiere que la secuencia basal se depositó durante el Triásico Temprano tardío-Triásico Medio temprano, la secuencia media durante el Triásico Medio y la secuencia superior durante el Triásico Tardío temprano.

Palabras clave: Triásico, Cuenca Cuyana, Sudoeste de Gondwana, Depocentro de Barreal-Calingasta, Paleofloras.

\section{Introduction}

The most complete Triassic basins of Southwestern Pangea are located near the Proto-Pacific margin of the South American plate. They are narrow and elongated depressions that are oriented NW-SE (Charrier, 1979), filled by continental sedimentation in Argentina and marine to transitional in Chile. The largest continental Triassic depocenter is the Cuyo (or Cuyana) Basin, which is floored on the Choiyoi Group, an intraplate Permian-Triassic plutonicvolcanic complex. It covers an area of $60,000 \mathrm{~km}^{2}$ and includes several depocenters filled with siliciclastic continental deposits (e.g., Borrello and Cuerda, 1965; Stipanicic, 2001; Barredo and Stipanicic, 2002). The Cuyo Basin corresponds to a continental rift basin developed as a result of generalized extension, induced by crustal thinning and collapse of the Upper Palaeozoic (Gondwana) orogen (Llambías and Sato, 1990, 1995; Spalletti, 1999) and the early Mesozoic Pangea breakup (e.g., Uliana et al., 1989; Barredo and Ramos, 1997; Zerfass et al., 2004). The basin shows strong asymmetric structural and depositional features, as well as intrabasinal highs and/or transfer zones that bind the different depocenters (Legarreta et al., 1992; Kokogian et al., 1988, 1993; Ramos and Kay, 1991; López Gamundi, 1994; Spalletti, 1999, 2001a; Rincón et al., 2011).
The northern part of the Cuyo Basin is known as the Rincón Blanco half-graben (Barredo and Ramos, 2010) and comprises the south-west of the San Juan province, Argentina. It has been interpreted that the passive margin of this half-graben was located at Barreal-Calingasta area, along the margin of Los Patos River, while the active margin was situated at Rincón Blanco area in Sierra del Tontal (López Gamundi, 1994; Barredo and Ramos, 2010; Spalletti, 2001b; Bonati et al., 2008) (Fig. 1).

The rocks deposited at the passive margin of Rincón Blanco half-graben are arranged into the Sorocayense Group (Mésigos, 1953). This unit is recognized as one of the iconic Triassic successions in Argentina, due to the continuity of the outcrops as well as the abundant fossiliferous strata (Groeber and Stipanicic, 1953; Bonetti, 1963; Stipanicic, 1972; Spalletti, 2001b). The richness of the palaeoflora is represented by one of the most diverse taxonomic assemblages of Gondwana, including plant impression-compressions and permineralized stumps and trunks (e.g., Stipanicic and Menéndez, 1949; Bonetti, 1968, 1972; Lutz and Herbst, 1992; Ganuza et al., 1998; Zamuner et al., 1999; Bodnar, 2008; Bodnar et al., 2015; Ruiz and Bodnar, 2019). Nevertheless, there still remain controversies and uncertainties about stratigraphic correlations, palaeoenvironmental interpretations, biostratigraphy, and age of these lithostratigraphic units. 


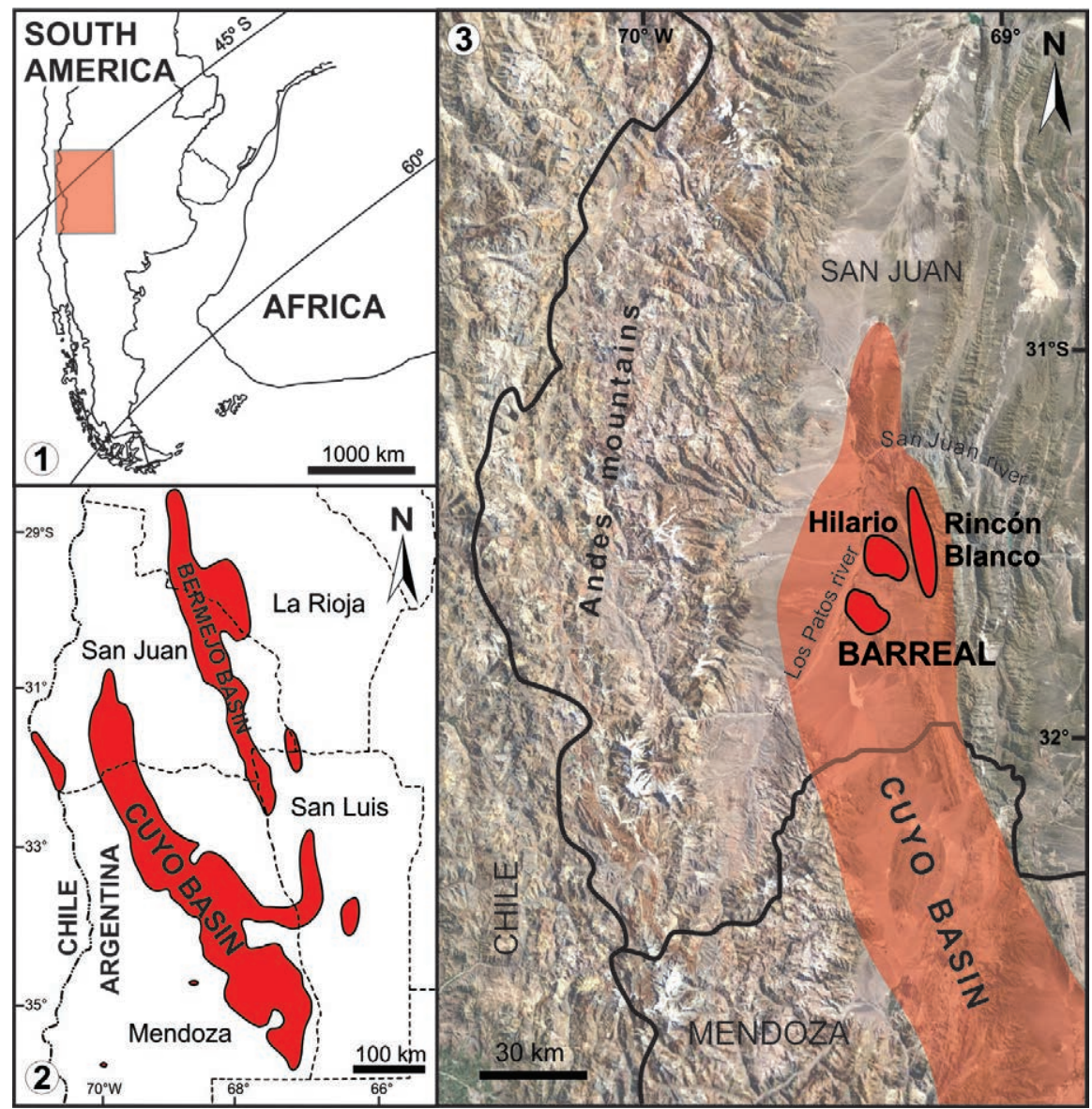

FIG. 1. 1. Location map of central Argentinean Triassic rift basins in the Southwestern Gondwana. 2. Triassic basins of central Argentina (modified from Stipanicic, 2002a; Barredo et al., 2012). 3. Location map of Barreal, Hilario and Rincón Blanco depocenters of Cuyo Basin at the Southwst of San Juan province, Argentina. Satellite imagen taken from Google Earth Pro.

The purpose of this paper is threefold. First, we propose a new stratigraphic scheme for the Sorocayense Group in the Barreal depocenter and a reinterpretation of the depositional environments of the units. Second, we organize the plant fossil strata and analyze their taxonomic composition along the stratigraphic column with the purpose of establishing floristic changes during Triassic. Finally, we integrate the stratigraphic, sedimentological, and palaeofloristic information in order to infer the palaeoclimate, and adjust the geological correlation and age of the lithostratigraphic units of the Sorocayense Group.

\section{Geological setting}

The Triassic sedimentary succession of the western San Juan Precodillera outcrops in two zones:
Rincón Blanco (in the Sierra de Tontal) and BarrealCalingasta (in the valley of Los Patos river) (Figs. 2, 3). At the Barreal-Calingasta zone, the Triassic deposits are located mainly in the following two areas: nearby the town of Barreal and neighbouring Hilario. The first interpretations proposed that these rocks were deposited in two independent basins (Hilario and Barreal) (Stipanicic, 1947; Zöllner, 1950) or in one independent depositional basin (Stipanicic, 1957, 1972). Other authors considered the Triassic sediments of the San Juan Precordillera as part of the infilling of a more comprehensive basin (Rolleri and Criado Roque, 1968; Yrigoyen and Stover, 1970; Stipanicic, 1979, 1983; Strelkov and Álvarez, 1984; Kokogian and Mancilla, 1989; Kokogian et al., 1999, 2001; López Gamundi, 1994). According to Strelkov and Álvarez (1984), and Kokogian and 


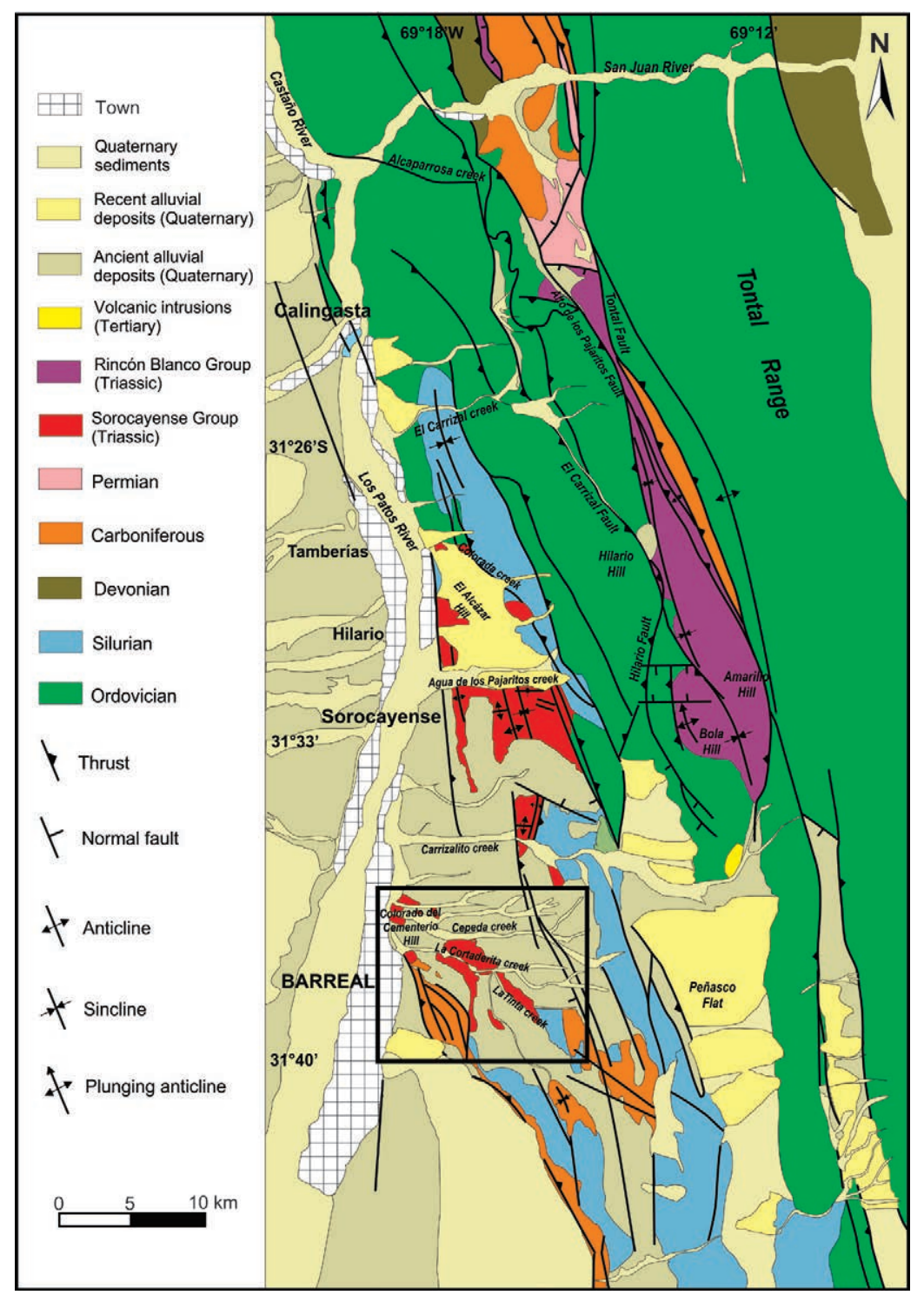

FIG. 2. Geological map of the Rincón Blanco half-graben with detailed information from the Barreal, Hilario and Rincón Blanco depocenters. The box indicates the location of the studied area. Redrawn and modified from Barredo (2012).

Mancilla (1989), all Argentinean Triassic deposits, from Barreal (San Juan Province) to General Alvear (Mendoza Province), belong to a single basin known as Mendocina-Sanjuanina or Cuyo (or Cuyana) Basin. This basin consists of sub-basins of Alvear (Criado Roque, 1979), Cacheuta (Rolleri and Fernández Garrasino, 1979), Rincón Blanco (Stipanicic, 1972), and Barreal-Calingasta (Stipanicic, 1972).

More recently, it was suggested that the deposits of the Barreal-Calingasta area, named as Sorocayense
Group by Mésigos (1953), together with the Rincón Blanco succession, referred to as Rincón Blanco Group by Borrello and Cuerda (1965), represent the record of a strongly asymmetrical half-graben named Rincón Blanco (Barredo and Ramos, 1997, 2010). The ramp would be located towards the West (at Barreal-Calingasta) and the tectonically active border fault towards the SouthEast (at Rincón Blanco), which explains the lithological differences between these two areas (López Gamundí, 1994; Barredo and Ramos, 1997, 2010). 

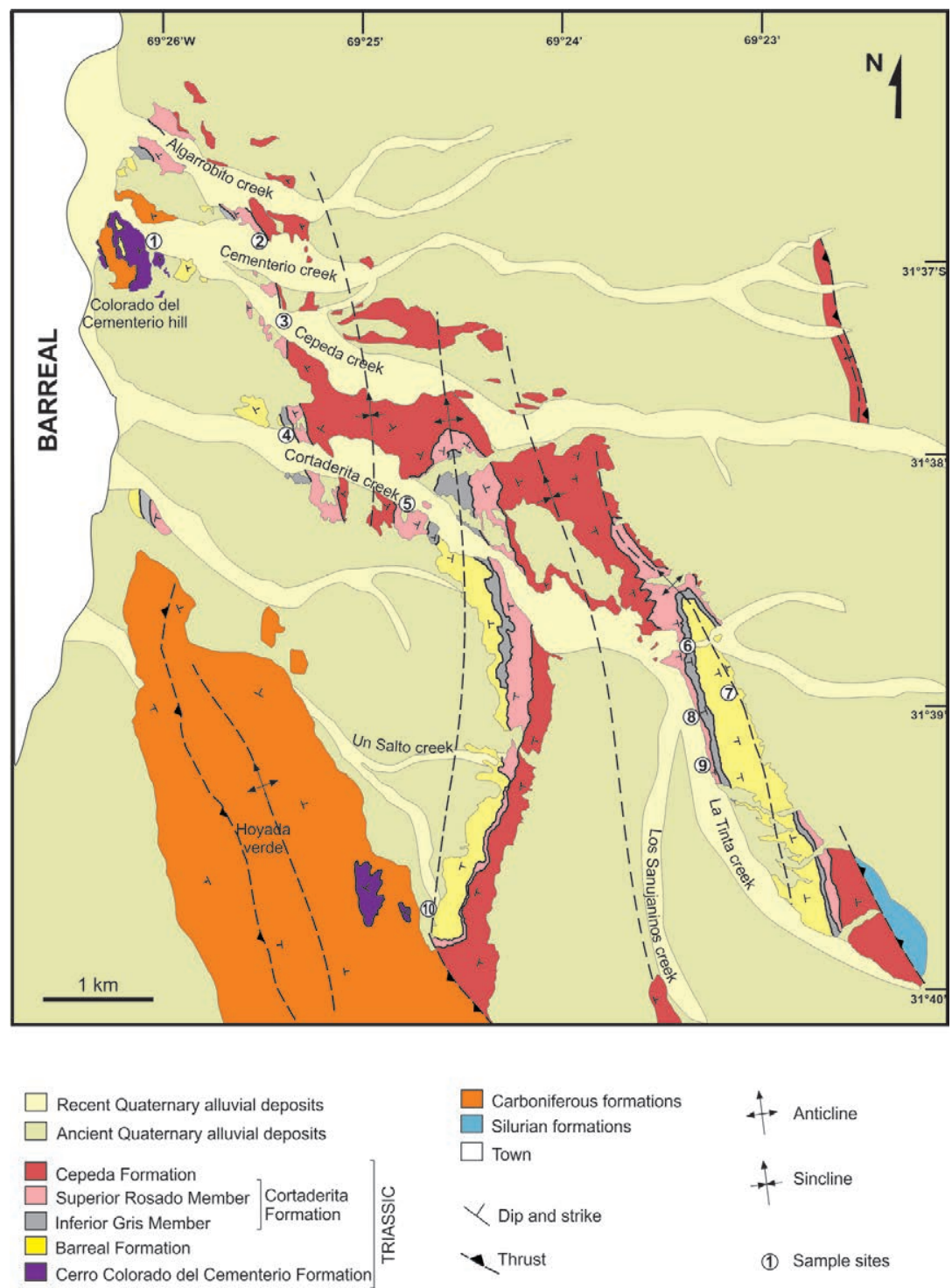

FIG. 3. Geological map of Barreal depocenter. Based on maps published by Quartino et al. (1971), Bonati et al. (2008), and satellite imagens taken from Google Earth Pro. The numbers 1 to 10 show the sampled sites in this study.

Rincon Blanco Triassic succession differs from that of the Barreal-Calingasta, because it emerges in a narrow and deep depression, has higher relief, is considerably thicker (3000 m thick in Rincón Blanco, Barredo et al., 2012, and up to $1400 \mathrm{~m}$ thick in BarrealCalingasta, Abarzúa, 2016), and is more complete (Rolleri and Criado Roque, 1968; López Gamundí, 1994; Stipanicic, 2002a). Typically, the coarse-basal sediments (fanglomerates) are more than 10 times thicker than the passive margin of halfgraben (up to
1200 m thick in Rincón Blanco, López Gamundi, 1994; Barredo et al., 2012; and up to $100 \mathrm{~m}$ in Barreal-Calingasta, Abarzúa, 2016). Conversely, the Barreal-Calingasta succession crops out in a broad band at the east of Hilario, Sorocayense, and Barreal towns, and displays soft relief (Kokogian et al., 2001).

The region between Barreal and Hilario towns is characterized by a series of east-west oriented creeks, where the Sorocayense Group is exposed. From north to south, they are: El Alcázar, Agua de los Pajaritos, 
El Carrizal, Algarrobito, Cepeda, La Cortaderita, La Tinta, Los Sanjuaninos and Un Salto creeks (Fig. 2). The Sorocayense Group is highly affected by tectonic deformation, resulting in broad folding with synclines and anticlines, and faults; consequently, the stratigraphic column is repeated at several places with north-south orientation along the area between Barreal and Hilario. The Sorocayense Group comprises three, four or five formations, depending on the authors (Groeber and Stipanicic, 1953; Baraldo and Guerstein, 1984; Barredo, 2012), at Hilario depocenter, and three formations in Barreal. At this last depocenter, the group was divided from the base to the top into the Barreal, Cortaderita, and Cepeda formations (Groeber and Stipanicic, 1953; Stipanicic, 1972).

Some authors proposed that the Triassic succession of the Sorocayense Group begins with a sequence of volcanic beds (ignimbrites and tuffs) and porfiritic conglomerates outcropping at Colorado del Cementerio hill and Un Salto creek (Frenguelli, 1948; Zöllner, 1950; Mésigos, 1953; Groeber and Stipanicic, 1953; Quartino et al., 1971; Stipanicic, 1972, 1979; López Gamundí and Martínez, 2003). Previously, Heim (1945) described this sequence as "caps of red quartz-porphyry", integrated by quartz porfid layers, tuffs, conglomerates, and breccias, overlying the Carboniferous rocks in disconformity and underlying the Triassic succession. However, Damborenea (1974), and Damborenea and Stipanicic (2002) argued that these ignimbrites and tuffs would be Cenozoic in age. Most recent works (Bonatti et al., 2008; Tapia Baldis, 2013; Abarzúa, 2016; Rocher et al., 2016) supported the Triassic age for these rocks, and included them in the base of Barreal Formation.

Furthermore, there is a discrepancy with respect to the age of the Barreal Formation (Groeber and Stipanicic, 1953), which is mostly based on the preserved palaeofloras. Spalletti et al. (1999) proposed that this unit is not younger than early Middle Triassic, while Stipanicic and Spalletti (2002a) suggested that it should be placed at the latest Middle Triassic or, at the earliest Late Triassic.

The middle unit of the Sorocayense Group, the Cortaderita Formation (Groeber and Stipanicic, 1953), has been also subjected to different stratigraphic proposals. According to Stipanicic $(1972,1979)$, this unit overlies the Barreal Formation through an erosive unconformity. On the other hand, Spalletti (2001b) sustained that the boundary between Barreal and Cortaderita formations is represented by a flooding surface, limiting two different lacustrine systems. Besides, the Cortaderita Formation was divided into two sections by Spalletti et al. (1999), and later Spalletti (2001b) and Morel et al. (2001, 2003) suggested the existence of a regional unconformity, with an important hiatus between these sections. However, the divisions of the Cortaderita Formation sections have not been defined as formal members yet. Otherwise, the age of Cortaderita Formation is also controversial; while Stipanicic $(1972,1979)$ considered it as early Late Triassic, Spalletti et al. (1999) assigned the lower section into the late Middle Triassic and the upper section into the middle Late Triassic, based on the preserved plant assemblages.

Finally, the uppermost unit of the Sorocayense Group, the Cepeda Formation, overlies the Cortaderita Formation through an erosive unconformity, and is generally considered as late Late Triassic in age (Stipanicic, 1972; Morel et al., 2001; Spalletti, 2001b; Stipanicic and Spalletti, 2002b).

\section{Palaeontological background}

Stappenbeck (1910) was the first to publish a fossil plant list (determined by Kurtz) from the Barreal-Calingasta region, which was obtained from the Agua de los Pajaritos creek (Fig. 2). Later, Du Toit (1927a, b) suggested the presence of the flora of "Thinnfeldia" at Agua de los Pajaritos and Un Salto creeks, showing similarities with the palaeofloras of Australia and Africa.

Frenguelli (1944) collected and studied fossil leaves assigned to the genus Zuberia (Corystospermales) at the La Cortaderita creek. Later, the same author established and described four plant-bearing strata at the La Cortaderita and Un Salto creeks (Frenguelli, 1948). The lowest stratum bears the previously studied Zuberia leaves; the second stratum is characterized by silicified trunks, together with corystosperms (Zuberia spp.; Johnstonia stelzneriana) and ginkgoales (Saportaea spp.) leaves; the third includes the taphofloras studied by Du Toit (1927a, b), equisetales (Phyllotheca australis, Equisetites fertilis), corystosperms (Xylopteris elongata), and gnetales (Yabeiella mareyesiaca); and finally, the fourth stratum contains the fossil assemblage published by Stappenbeck (1910).

Stipanicic and Menéndez (1949) described fossil leaves of dipterid ferns, coming from the the Barreal Formation, at the La Cortaderita creek. Subsequently, 
Stipanicic and Bonetti (in Groeber and Stipanicic, 1953) reorganized the Barreal taphlofloras into three fossiliferous levels (=NF). The fossil content, the stratigraphic position, and the outcropping points of these levels, were later studied in detail by Bonetti $(1963,1968,1972)$. The NFI from the Barreal Formation consisted of the dipteridacean leaves studied by Stipanicic and Menéndez (1949), corystosperms, and ginkgoales. The NFII from the Cortaderita Formation contained leaves and ovulebearing structures of corystosperms and gnetales. The NFIII, also from the Cortaderita Formation, comprised silicified trunks of Rhexoxylon cortaderitaense (first described as conifers by Menéndez, 1956, and later assigned to corystoperms by Bodnar, 2008), and leaves of corystosperms and cycadales.

Artabe et al. (1995, 2001) suggested another scheme for the Barreal-Calingasta plant strata, establishing its correspondence with that proposed by Bonetti (1963), adding new levels and taxa. They defined four fossiliferous strata in the Barreal Formation and two in the Cortaderita Formation. The lowest Barreal stratum is characterized by the presence of corystosperms and gnetales leaves; the second stratum presents by osmundales and peltasperm leaves; the third stratum coincides with the NFI of Bonetti (1963); and the fourth stratum contains gikgoalean leaves. The third stratum of the Barreal Formation was later used by Spalletti et al. (1999) as the type stratum for the early Middle Triassic biozone Dictyophyllum castellanosii-Johsntonia stelzneriana-Saportaea dichotoma (CSD). Its diagnostic elements are as follows: Dictyophyllum castellanosii, Thaumatopteris barrealensis, Zuberia feistmanteli, Z. barrealensis, Dicroidium dubium, Johsntonia stelzneriana, S. flabellata, S. dichotoma, S. intermedia, and Heidiphyllum elongatum.

The lower fossiliferous stratum of Cortaderita Formation, as described by Artabe et al. (1995), was characterized by in situ trunks and stumps of corystosperms and conifers, associated with leaf and stem impressions of equisetales, cycadales, and peltasperms (the latter were studied in detail by Zamuner et al., 1999). This fossiliferous level was used by Spalletti et al. (1999) as the type stratum for the late Middle Triassic biozone Yabeiella mareyesiaca-Scytophyllum bonettiae-Protophyllocladoxylon cortaderitaense (MBC), whose diagnostic elements are Yabeiella marayesiaca, Scytophyllum bonettiae, Rhexoxylon (=Protophyllocladoxylon) cortaderitaensis, Zuberia feistmanteli, Zuberia zuberi, Cuneumxylon spallettii, Pachydermophyllum praecordillerae, Kurtziana cacheutensis, and Agathoxylon protoaraucana. The upper stratum of Cortaderita is equivalent to the NFIII of Bonetti (1963). Spalletti et al. (1999) and Morel et al. (2001) identified in the in upper stratum of the Cortaderita Formation, the middle Late Triassic biozone Dicroidium odontopteroides-D. lancifolium (OL), whose diagnostic elements are Dicroidium odontopteroides, D. lancifolium, and Yabeiella brackesbuschiana.

Artabe et al. (2001) interpreted the plant palaeocomunities of the Barreal and Cortaderita formations on the basis of the preserved taphocoenosis. In the third fossiliferous stratum from the Barreal Formation, they inferred a seasonal subtropical evergreen forest dominated by corystosperms both in the canopy and the understory. In the lower stratum of the Cortaderita Formation, they distinguished three types of palaeocomunities: a seasonal subtropical evergreen forest constituted by corystosperms and conifers, sphenophyte shrublands, and a subtropical sclerophyll forest dominated by corystosperms. In the upper stratum of the Cortaderita Formation, they described an herbaceous-shrubby palaeocomunity composed mainly of corystosperms.

Afterwards, Bodnar (2010) defined eight fossiliferous strata $(\mathrm{EF})$ in the Cortaderita Formation. The fossiliferous strata EF2, EF3, and EF4, represent horizons with in situ fossil forests. They are composed of permineralized trunks and stumps, and impression-compressions of leaves and branches. More recently, Bodnar et al. (2015) described two fossiliferous strata (EF) in the Barreal Formation and nine in the Cortaderita Formation, whose fossil content was partially studied (particularly the conifer fossil remains). Table 1 summarizes the location and correlation of the fossiliferous strata, as described by the different authors.

With respect to the Cepeda Formation, Herbst (1995) described the first and unique fossil plants for the unit, which correspond to the permineralized osmundaceous stems of Millerocaulis stipabonetti associated with at least one trunk of Rhexoxylon.

\section{Methodology}

The studied area is located at west-central Argentina, in the south-west of San Juan Province (Fig. 1), $4 \mathrm{~km}$ the east of Barreal town (Figs. 2, 3). As 


\begin{tabular}{|c|c|c|c|c|c|c|c|c|c|c|c|c|}
\hline \multirow{2}{*}{\multicolumn{2}{|c|}{ Unit }} & $\begin{array}{c}\text { Frenguelli } \\
\text { (1948) }\end{array}$ & \multicolumn{2}{|r|}{ Bonetti (1963) } & \multicolumn{3}{|c|}{ Artabe et al. (1995) } & \multicolumn{2}{|c|}{ Bodnar (2010) } & \multicolumn{3}{|r|}{ This work } \\
\hline & & FS & FS & Localities & \multicolumn{2}{|c|}{ FS } & Localities & FS & Localities & FS & Localities & Correlation \\
\hline \multirow{9}{*}{ 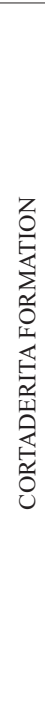 } & \multirow{4}{*}{ 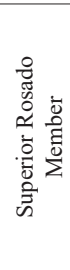 } & \multirow[t]{4}{*}{$\begin{array}{l}\text { Fourth } \\
\text { stratum }\end{array}$} & \multirow[t]{4}{*}{ NF III } & \multirow{4}{*}{$\begin{array}{c}\text { Cortaderita creek } \\
\text { (points } 30,31,32,33, \\
34 \text { and } 35 \text { ) } \\
\text { La Tinta creek (point } \\
\text { 36) }\end{array}$} & \multirow{4}{*}{\multicolumn{2}{|c|}{ Upper Section f. 1.}} & \multirow{4}{*}{$\begin{array}{l}\text { Cortaderita } \\
\text { creek }\end{array}$} & EF8 & La Tinta creek & EF12 & 8 & $\begin{array}{l}\text { NFIII (point 36) (Bonetti, 1963), } \\
\text { EF7 (Bodnar, 2010) }\end{array}$ \\
\hline & & & & & & & & EF7 & La Tinta creek & EF11 & 5 & EF8 (Bodnar, 2010) \\
\hline & & & & & & & & EF6 & Cortaderita creek & EF11 & 5 & $\begin{array}{l}\text { NFIII (point 32) (Bonetti, 1963), } \\
\text { EF5-EF6 (Bodnar, 2010), Upper } \\
\text { Section f. 1. (Artabe } \text { et al., 1995) }\end{array}$ \\
\hline & & & & & & & & EF5 & Cortaderita creek & EF9 & 6 & First stratum of Frenguelli (1948) \\
\hline & \multirow{5}{*}{ 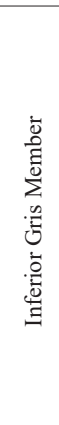 } & \multirow{5}{*}{$\begin{array}{l}\text { Third } \\
\text { stratum }\end{array}$} & \multirow[t]{5}{*}{ NF II } & \multirow{5}{*}{$\begin{array}{c}\text { Cortaderita creek } \\
\text { (point 22) } \\
\text { Un Salto creek (points } \\
20 \text { and 21) }\end{array}$} & \multirow{5}{*}{$\begin{array}{l}\text { Lower Sec- } \\
\text { tion f.s. }\end{array}$} & \multirow[b]{2}{*}{ Level 3} & \multirow[b]{2}{*}{ La Tinta creek } & \multirow[b]{2}{*}{$\mathrm{EF} 4$} & \multirow[b]{2}{*}{ La Tinta creek } & EF8 & 8 & EF4 (Bodnar, 2010) \\
\hline & & & & & & & & & & EF7 & 8 & $\begin{array}{l}\text { NFI (point 12) and NF II (point 22) } \\
\text { (Bonetti, 1963), Level } 3 \text { of Lower } \\
\text { Section f.s. (Artabe et al., 1995), EF3 } \\
\text { (Bodnar, 2010) }\end{array}$ \\
\hline & & & & & & Level 2 & La Tinta creek & $\mathrm{EF} 3$ & La Tinta creek & EF8 & 6,9 & $\begin{array}{l}\text { Level } 3 \text { of Lower Section f.s. } 3 \\
\text { (Artabe } \text { et al., 1995), EF2 } \\
\text { (Bodnar, 2010) }\end{array}$ \\
\hline & & & & & & \multirow{2}{*}{ Level 1} & \multirow{2}{*}{ La Tinta creek } & $\mathrm{EF} 2$ & La Tinta creek & EF5 & 6 & $\begin{array}{l}\text { Level } 2 \text { of Lower Section f.s. (Artabe } \\
\text { et al., 1995), EF1 (Bodnar, 2010) }\end{array}$ \\
\hline & & & & & & & & $\mathrm{EF} 1$ & Cortaderita creek & EF4 & 4,6 & $\begin{array}{l}\text { Level } 1 \text { of Lower Section f.s. (Artabe } \\
\text { et al., 1995) }\end{array}$ \\
\hline \multirow{10}{*}{\multicolumn{2}{|c|}{ 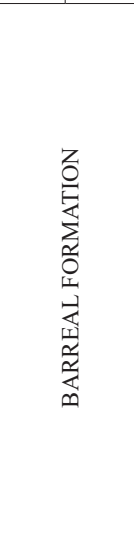 }} & \multirow[t]{3}{*}{$\begin{array}{l}\text { Second } \\
\text { stratum }\end{array}$} & \multirow[t]{8}{*}{ NF I } & \multirow{8}{*}{$\begin{array}{c}\text { Cortaderita creek } \\
\text { (point 11) } \\
\text { La Tinta creek (point } \\
\text { 12) }\end{array}$} & \multicolumn{2}{|c|}{ f. s. 4} & \multirow[t]{6}{*}{$\begin{array}{c}\text { Cortaderita } \\
\text { creek }\end{array}$} & & & & & $\begin{array}{l}\text { NFI (point 11) and NFII (points } 20 \\
\text { and 21) (Bonetti, 1963); f.s. } 3 \text { (Artabe }\end{array}$ \\
\hline & & & & & \multirow{5}{*}{ f. s. 3} & Level 5 & & & & & & \\
\hline & & & & & & Level 4 & & & & & & \\
\hline & & \multirow[t]{5}{*}{ First stratum } & & & & Level 3 & & & & & & \\
\hline & & & & & & Level 2 & & & & EF3 & 4,10 & \\
\hline & & & & & & Level 1 & & & - & & & \\
\hline & & & & & f. $\mathrm{s}$ & & $\begin{array}{l}\text { Cortaderita } \\
\text { creek }\end{array}$ & & & & & \\
\hline & & & & & f. s & & $\begin{array}{l}\text { Cortaderita } \\
\text { creek }\end{array}$ & & & & & \\
\hline & & & & & & & & & & EF2 & 7 & - \\
\hline & & & & & & & & & & EF1 & 7 & - \\
\hline
\end{tabular}


part of this investigation, sedimentological sections were made at 1:100 scale in the outcrops eastwards of Barreal town, including the localities of Colorado del Cementerio hill, together with the Cepeda, La Cortaderita, La Tinta, and Un Salto creeks (Fig. 3). In addition, an unnamed creek was surveyed, which begins at the Colorado del Cementerio hill and was informally identified here as "Cementerio creek". All sampled sites were precisely located using geological maps, satellite images from Landsat ETM 232/82, and images from Google Earth Pro, and located in the map of figure 3 with numbers from 1 to 10 .

The sedimentological characterization of the field comprised grain size, rock colour, mineral composition, primary sedimentary structures, body geometry, and vertical and horizontal contacts between successive rock bodies. Based on this information, lithofacies were defined following Miall $(1978,1996)$ (Table 2). Thin sections of rock samples were also analysed to characterize the diagenetic cements and the provenance of the sediments. Palaeosol levels were identified and described following the criteria of Terruggi (1971), Andreis (1981), and Retallack (1988). They were classified following Retallack (1988), Mack et al. (1993), and the Soil Survey Staff (1999). Petrographic slides and palaeosols analyses by X-ray diffraction were realized at the laboratory of Centro de Investigaciones Geológicas (CIG-CONICET, Universidad Nacional de La Plata).

All the previously described fossil plant bearing strata were recognized and precisely placed in the respective stratigraphic sections. Fossil plants were taxonomically and taphonomically characterized. The new fossil materials were deposited in the Paleobotanical Collection of the Museo de Ciencias Naturales at the Universidad Nacional de San Juan, under the numbers PBSJ 408-457; 608-657; 730-850, 1043-1053. Furthermore, fossils previously collected and studied by Frenguelli (1944), Menéndez (1956), Bonetti (1963), Lutz and Herbst (1992), and Zamuner et al. (1999), were also revised. These materials are deposited in the palaeobotanical collections of the Museo Argentino de Ciencias Naturales "Bernardino Rivadavia", Universidad Nacional del Nordeste and Museo de La Plata, under the acronyms BAPb/BAPbPm, CTES-PB/PMP-CTES and LPPB/pmLPPB respectively. The photographs of the specimens were taken with Canon Powershot S40 and Canon EOS Rebel T3i digital cameras.

The floristic diversity was evaluated using the species richness (number of species) per fossiliferous stratum.
The curves of species richness were obtained with the help of the PAST software (version 3.18 beta), using the "range-through assumption" (Hammer et al., 2001).

\section{Stratigraphy and sedimentology}

On the basis of stratigraphic correlations, bed relationships and sedimentological features, we defined three tectosedimentary sequences for the Sorocayense Group: basal (Lower Triassic-lower Middle Triassic), middle (Middle Triassic), and upper (Upper Triassic).

\subsection{Basal sequence of Sorocayense Group}

The basal sequence overlies by an angular unconformity over the Carboniferous-Permian lithostratigraphic units, which is characterized by folded laminated fine-grained sandstones and siltstones (Mésigos, 1953; Spalletti, 2001a). Though this succession was considered as part of the Barreal Formation (Stipanicic, 1972, 1979; Bonati et al., 2008; Tapia Baldis, 2013; Abarzúa, 2016; Rocher et al., 2016, see "Discussions"), here we separated it from that unit on the basis of the lithological characteristics, and recognized it as a new lithostratigraphic unit called Cerro Colorado del Cementerio Formation. In the entire basal sequence, no fossil strata were found.

\subsubsection{Cerro Colorado del Cementerio Formation}

The type section for this member is defined at Colorado del Cementerio hill between $31^{\circ} 36^{\prime} 59^{\prime \prime} \mathrm{S} / 69^{\circ} 27^{\prime} 7,6^{\prime \prime} \mathrm{W}$ and $31^{\circ} 36^{\prime} 45,7^{\prime \prime} \mathrm{S} / 69^{\circ} 26^{\prime} 58,9^{\prime \prime} \mathrm{W}$, although it can be also recognized in the Cementerio and Un Salto creeks. It overlies by an angular unconformity over the Pituil Formation (Upper Carboniferous), and is covered by the Barreal Formation by an erosive unconformity. The Cerro Colorado del Cementerio Formation has a thickness of $75 \mathrm{~m}$. This unit can be divided into four sections, which are well represented at Colorado del Cementerio hill, while only the two lower sections outcrop in the Un Salto creek. The section 1 (Figs. $4.1,4.8)$ displays a variable thickness, reaching a maximum of $2 \mathrm{~m}$ and filling a Palaeozoic palaeorelief over an angular unconformity (Fig. 4.2). It consists of lenticular bodies of matrix-supported polymictic conglomerates (lithofacies Gmm, Table 2). Most of the lithoclasts are subrounded volcanic and angular Palaeozoic blocks up to $20 \mathrm{~cm}$ in diameter (Figs. 4.2, 5). 
TABLE 2. LITHOFACIES CODE USED IN THIS WORK (MODIFIED FROM MIALL, 1996).

\begin{tabular}{|c|c|c|}
\hline $\begin{array}{l}\text { Lithofacies } \\
\text { Code }\end{array}$ & Description & Interpretation \\
\hline Gmm & $\begin{array}{l}\text { Massive, matrix-supported, pebble-cobble polymictic conglo- } \\
\text { merates, with subrounded or highly angular volcanic clasts } \\
\text { and lithoclasts (fanglomerates) }\end{array}$ & Plastic debris flow (high-strength, viscous) \\
\hline Gcm & $\begin{array}{l}\text { Massive, clast-supported, pebble-cobble oligomictic conglo- } \\
\text { merates, with rounded lithoclasts }\end{array}$ & $\begin{array}{l}\text { Pseudoplastic debris flow (inertial bedload, } \\
\text { turbulent flow) }\end{array}$ \\
\hline Gcg & $\begin{array}{l}\text { Massive, clast-supported, pebble-cobble polymictic conglo- } \\
\text { merates, with subrounded volcanic clasts and lithoclasts }\end{array}$ & $\begin{array}{l}\text { Subaqueous mass flow deposits (intake of water); } \\
\text { least viscous and partly turbulent flow }\end{array}$ \\
\hline Gh & $\begin{array}{l}\text { Horizontally stratified, pebble and cobble polymictic con- } \\
\text { glomerates, with subangular sandy and volcanic tuffaceous } \\
\text { intraclasts and imbricate pebbles }\end{array}$ & Lag deposits \\
\hline Gp & $\begin{array}{l}\text { Planar cross-stratified, granule and pebble conglomerates, } \\
\text { with tuffaceous and quartz clasts }\end{array}$ & Transverse bedforms \\
\hline Gt & $\begin{array}{l}\text { Trough cross-stratified, granule and pebble polymictic con- } \\
\text { glomerates, with abundant pyroclastic pebbles. }\end{array}$ & Minor channel fills \\
\hline $\mathrm{Sm}$ & Massive coarse, medium and fine sandstones & Deposits of sediment gravity flows \\
\hline Ss & $\begin{array}{l}\text { Medium to coarse-grained and pebbly sandstones, with silty } \\
\text { intraclasts and tuffaceous matrix, with cut and fill structures }\end{array}$ & Scour fill \\
\hline $\mathrm{Sh}$ & $\begin{array}{l}\text { Horizontal laminated red and yellowish fine to medium-grai- } \\
\text { ned sandstones, pebbly sandstones and granule conglomerates }\end{array}$ & Planar bed flow (lower flow regime) \\
\hline St & $\begin{array}{l}\text { Trough cross-stratified medium to coarse-grained sandstones, } \\
\text { with rounded quartz and tuffaceous clasts }\end{array}$ & Sinuous-crested and linguoid (3D) dunes \\
\hline $\mathrm{S} 1$ & $\begin{array}{l}\text { Horizontal to low angle cross laminated, very fine to medium } \\
\text { sandstones }\end{array}$ & Planar bed flow (upper flow regime, critical flow) \\
\hline $\mathrm{Sr}$ & $\begin{array}{l}\text { Ripple laminated fine to coarse grained sandstones and pebbly } \\
\text { sandstones, }\end{array}$ & Ripples (lower flow regime) \\
\hline $\mathrm{Sp}$ & Cross-stratified fine to medium sandstones & Transversal to linguoids bed forms ( $2 \mathrm{D}$ dunes) \\
\hline Smp & $\begin{array}{l}\text { Massive fine to coarse grained sandstones and tuffaceous } \\
\text { sandstones, with pedogenetic features }\end{array}$ & Overbank with incipient palaeosols \\
\hline $\mathrm{Fr}$ & $\begin{array}{l}\text { Massive, bentonitic siltsones and silty sandstones, with slic- } \\
\text { kensides, cutans and root traces }\end{array}$ & Floodplain with palaeosols \\
\hline Fsm & $\begin{array}{l}\text { Massive, tuffaceous and bentonitic siltstones, with abundant } \\
\text { organic matter }\end{array}$ & Backswamps or abandoned channel deposits \\
\hline Fm & $\begin{array}{l}\text { Massive, bentonitic claystones with iron nodules, redoximor- } \\
\text { phic features and bioturbation }\end{array}$ & $\begin{array}{l}\text { Overbank, abandoned channel, or drape deposits, } \\
\text { incipient soil }\end{array}$ \\
\hline F1 & $\begin{array}{l}\text { Very fine sandstones, siltstones and claystones, with fine } \\
\text { lamination and very small ripples }\end{array}$ & $\begin{array}{l}\text { Overbank, abandoned channel, or waning flood } \\
\text { deposits }\end{array}$ \\
\hline $\mathrm{P}$ & Evaporite and calcrete levels & Indurated soil, duricrust \\
\hline $\mathrm{T}$ & $\begin{array}{l}\text { Grey to greenish bentonite and tuffs. Mottles, slickensides, } \\
\text { bioturbation, root marks, blocky structure, nodules, carbo- } \\
\text { nized wood and branches, abundant leaf and reproductive } \\
\text { compressions, in situ stumps }\end{array}$ & $\begin{array}{l}\text { Ash-fall beds, some completely devitrified } \\
\text { (weathered volcanic glass) }\end{array}$ \\
\hline I & Purplish red rhyolitic ignimbrite & Pyroclastic flow deposit \\
\hline
\end{tabular}


These rocks have been interpreted as sedimentgravity-flow deposits (debris-flow) accumulated in mid to proximal facies of an alluvial fan system.

Section 2 is recognized at the south face of the Colorado del Cementerio hill and along the Un Salto creek (Fig. 4.1). This deposit has been broadly draped over the pre-existing topography, reaching $20 \mathrm{~m}$ in thickness. Consequently, where section 1 is absent, section 2 overlies directly Palaeozoic rocks through an erosive angular unconformity, while in other places there is a net contact with section 1. Although the upper limit is obscured by Quaternary cover, the homoclinal arrangement of this deposit with respect to the other units of the Triassic succession supports the inclusion of this section as part of the Sorocayense Group. This unit corresponds to a volcaniclastic level, which consists of purplish red rhyolitic ignimbrites (lithofacies I, Table 2), with a very fine-grained matrix, abundant quartz, calcite, feldspar crystals, and little occurrence of small lithoclasts of Palaeozoic rocks (Figs. 4.3-5). Some of the pyroclastic bombs reach a diameter of $3 \mathrm{~cm}$. This section has been interpreted as pyroclastic flow (Table 2) that covered the previous deposits.

Section 3 is well exposed at Colorado del Cementerio hill and along the Cementerio creek (Fig. 4.8), and overlies section 1 or 2 through an erosive contact. It is a 20-meter thick succession, which is composed of tabular and lenticular bodies of the two following types: with plane base and convex top and with concave base and plane top. This succession consists of reddish oligomictic clast-supported conglomerates interfingering with massive coarse-sandstones (lithofacies Gcm and Sm, Table 2) (Fig. 5). At the base, the conglomerates have imbricated pebbles, mostly composed of rounded ignimbritic clasts from section 2 , of $\sim 10 \mathrm{~cm}$ in diameter, and sandy matrix (lithofacies Gh, Table 2) (Fig. 4.7). Section 3 would represent alluvial fan deposits interlayered with channels that display their terminal splays interlayered with sandy ephemeral playa lake facies.

Section 4 is recognized at the Colorado del Cementerio hill and along the Cementerio creek (Fig. 4.8). The lower contact of this unit corresponds to a net transition with section 3 . Section 4 reaches a maximum thickness of 30 meters and is composed of conglomerates and sandstones arranged in thin lenticular bodies, with erosive bases that form a finning upward succession of several cycles that are $5 \mathrm{~m}$ thick (lithofacies Gcg, Sh; Table 2; Fig. 5). The conglomerate facies are clast-supported, and polymictic with subrounded pebbles composed by previous ignimbrites (section 2) and other volcaniclastic rocks. This section can be interpreted as a succession of temporal channels and floodplains of an ephemeral fluvial system. This system appears to be in close relation with the alluvial fan and playa lake facies of section 3 .

\subsection{Middle sequence of the Sorocayense Group}

The second tectosedimentary sequence includes the Barreal and Cortaderita formations. The middle sequence preserves the most diverse and abundant palaeofloristic assemblages of the Rincón Blanco half-graben.

\subsubsection{Barreal Formation.}

The Barreal Formation is exposed in Colorado del Cementerio hill, and the Cementerio, Cortaderita, La Tinta and Un Salto creeks. This unit overlies the Cerro Colorado del Cementerio Formation by an erosive unconformity (Fig. 4.8), and is covered by the Cortaderita Formation through a transitional boundary. The thickness of the Barreal Formation is variable, ranging between $80-130 \mathrm{~m}$ and increasing towards the north-west. In general, the succession exhibits a decreasing grain size arrangement of the lithofacies, characterized by a dominance of coarse channelized deposits, with minor floodplain facies in the base, and a dominance of fine poorly drained floodplains and standing water facies together with abundant tuff and bentonitic layers near the top (Figs. 6.1-2). However, towards the north-west, in the La Cortaderita creek (Fig. 3) the upper part of the unit shows a higher proportion of coarse channelized facies.

The basal part of the Barreal Formation has been only recognized in the Colorado del Cementario hill and consists of $10 \mathrm{~m}$ of massive matrix-supported polymictic conglomerates (fanglomerates, lithofacies Gmm), composed of highly angular rhyolitic, psamitic and pelitic clasts -which reach up to one $\mathrm{m}$ in diameter- and mudstone matrix (Figs. 4.6, 7).

The formation continues with tabular beds, which are composed of horizontal or cross-stratified polymictic orthoconglomerates (lithofacies $\mathrm{Gh}, \mathrm{Gp}, \mathrm{Gt}$ ). These conglomerates contain pumice clasts up to $15 \mathrm{~cm}$ in diameter and other volcanic and lithic clasts of $\sim 8 \mathrm{~cm}$. They have a coarse sandy matrix and preserve abundant tree-trunks moulds. Furthermore, these 

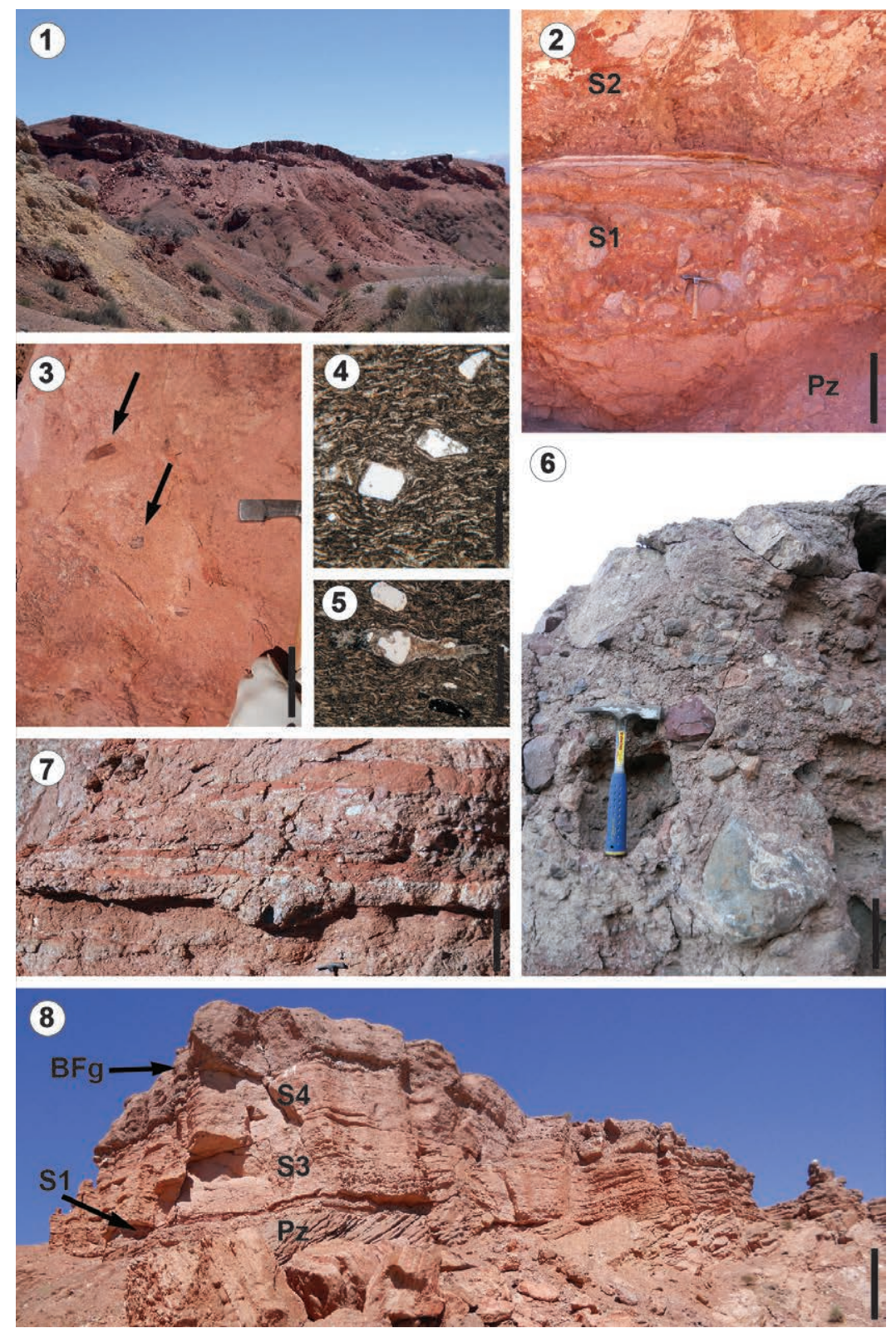

FIG. 4. Cerro Colorado del Cementerio Formation and basal part of Barreal Formation; 1. General view of the Cerro Colorado del Cementerio Formation, outcropping at Un Salto Creek; 2. Detail image of the contact between section 1 and section 2 at Un Salto creek; 3. Section 2 (Ignimbrite) with detail of the different types of clasts; $\mathbf{4 , 5}$. View of the ignimbrite of section 2 under optical microscope; 6. Basal fanglomerate of Barreal Formation; 7. Basal conglomerates of section 3 of Cerro Colorado del Cementerio Formation; 8. General view of the Cerro Colorado del Cementerio Formation and basal fanglomerate of Barreal Formation outcropping at Colorado del Cementerio hill. Abbreviations: $\mathbf{P z}=$ Paleozoic units; $\mathbf{S}=$ section; $\mathbf{B F g}=$ fanglomerate of Barreal Formation.Scale bars: $2=40 \mathrm{~cm} ; 3=10 \mathrm{~cm}, 4,5=0,1 \mathrm{~cm} ; 6=15 \mathrm{~cm} ; 7=30 \mathrm{~cm}, 8=10 \mathrm{~m}$.

beds are interlayered with minor lenticular bodies of sandstones (lithofacies Ss, St, Sm), and edafized fine grained sandstones and silstones (lithofacies Smp, Fsm) (Fig. 7).
Towards the top, this unit presents a coarsening upward arrangement, with massive and laminated grey claystones, siltstones, and silty sandstones (lithofacies Fm, Fsm and Fr, Table 2) -with abundant 
plant impressions-compressions and permineralized tree-trunks-interlayered with few lenticular and tabular bodies of massive sandstones and cross-stratified fine conglomerates ( $\mathrm{Sm}, \mathrm{Gp}$ and Gt, Table 2). The finest deposits are altered by soil development with bioturbation, root marks, redoximorphic features, slicken-sides, and scattered whitish nodules (Fig. 6.6).

Throughout all the formation, although more common towards the top, there are pink and greenish tuffs and bentonites (lithofacies T, Table 2), which bear abundant plant fossil material (mostly leaf impressions-compression and permineralized trunks).

On the basis of the facies arrangement, it is possible to interpret that the basal part of Barreal Formation corresponds to proximal alluvial fan deposits, dominated by sediment-gravity-flows (debris flow) that disappear towards the south-east of the depocenter. The lower and middle part of the unit is interpreted as high sinuosity gravel-sand meandering fluvial systems. In the upper part of the unit, floodplains began to expand, and temporal ponds or lakes would

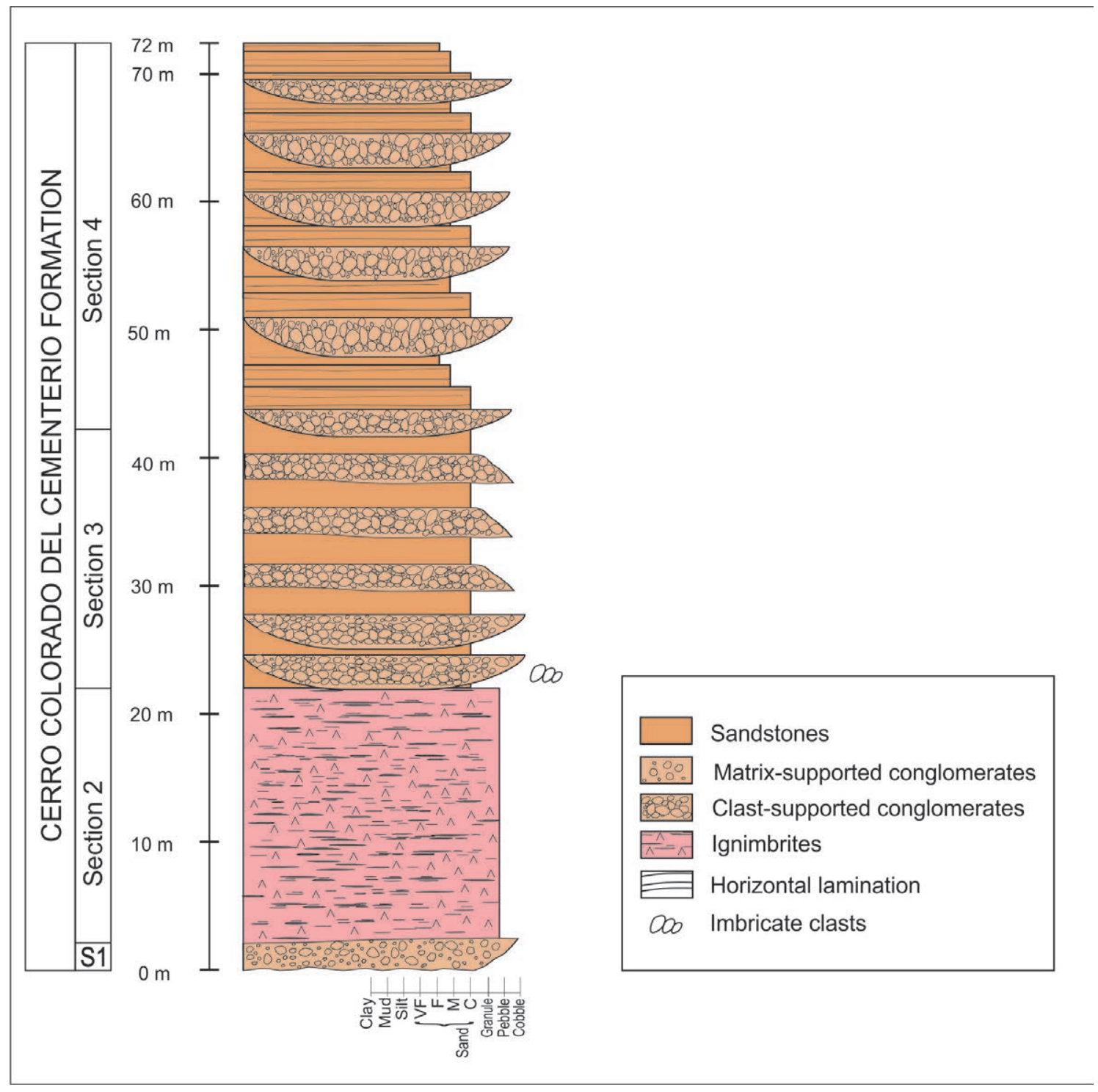

FIG. 5. General stratigraphic log of Cerro Colorado del Cementerio Formation. 

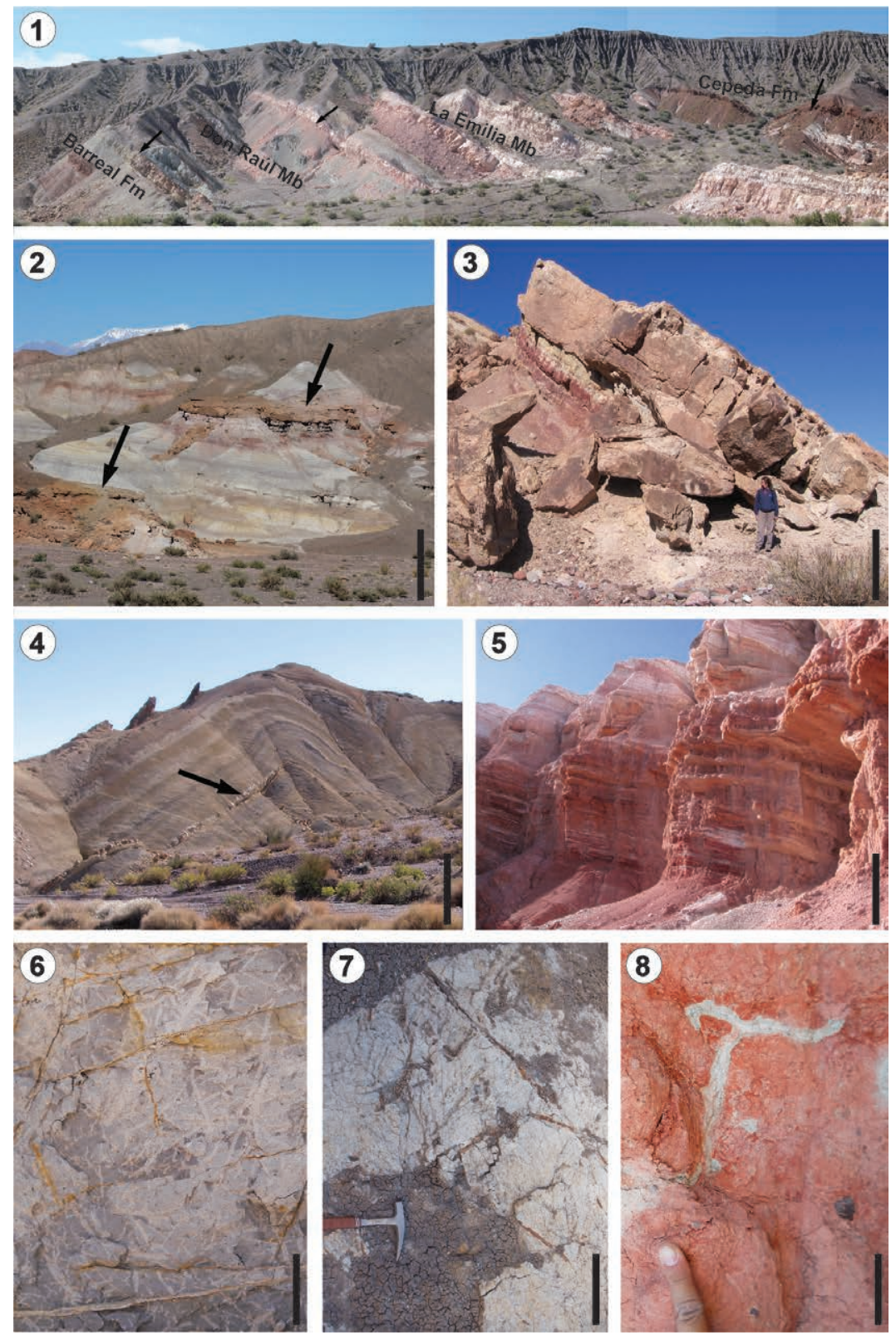

FIG. 6. Barreal and Cortaderita formations. 1. General view of the Barreal and Cortaderita formations at the type locality of Don Raúl Member and La Emilia Member at Cortaderita creek; 2. Barreal Formation. Arrows indicate conglomeratic and sandy channels; 3. Basal conglomeratic and sandy channel of Cortaderita Formation; 4. Don Raúl Member, the arrow points a tuff level; 5. Upper part of La Emilia Member; 6. Palaeosol with roots found in the Barreal Formation; 7. Palaeosol with roots found in Don Raúl Member; 8. Palaeosol with a rhizolith found in La Emilia Member. Abbreviations: Fm= Formation; $\mathbf{M b}=$ Member. Scale bars $2=5 \mathrm{~m} ; 3=1,5 \mathrm{~m} ; 4=4 \mathrm{~m} ; 5=3 \mathrm{~m} ; 6=4 \mathrm{~cm} ; 7=20 \mathrm{~m} ; 8=6 \mathrm{~cm}$.

have developed. Fluvial backwaters occasionally dried, allowing the development of gleyed-soils with hydromorphic and vertic properties. The increasing of pyroclastic material towards the top, represented by the ash-fall deposits, could locally affect the fluvial dynamic, causing the damming of the depositional system, and the burial and good preservation of paedomorphic features and plant remains. 


\subsubsection{Cortaderita Formation}

Well-exposed sections of the Cortaderita Formation crop out at the Cementerio, Cepeda, Cortaderita, La Tinta, and Un Salto creeks. It overlies the Barreal Formation in conformity through a transitional boundary and is covered by the Cepeda Formation by an angular unconformity. The Cortaderita Formation can be well subdivided into two sections, previously recognized by Spalletti et al. (1999), Spalletti (2001b) and Morel et al. (2001),

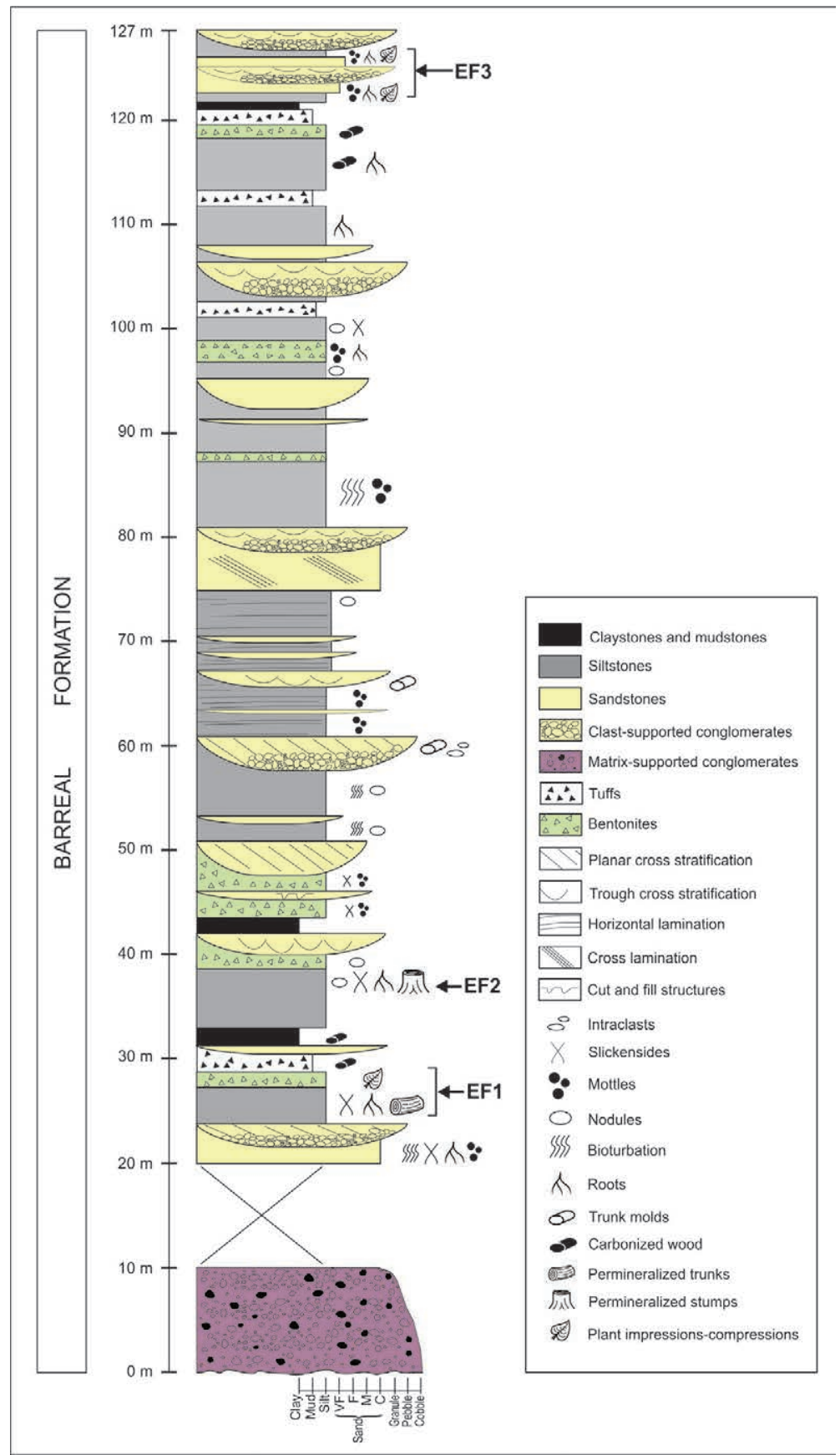

FIG. 7. General stratigraphic log of Barreal Formation. EF1 to EF3 indicate fossiliferous strata considered in this study. 
although formal designation was never published. A detailed description and a formal proposal of two lithostratigraphic members of the Cortaderita Formation, Don Raúl and La Emilia, are proposed here. The names come from the bentonite mines near the type sections locality in the Cortaderita creek (see Hidalgo et al., 2016).

\subsubsection{Don Raúl Member of the Cortaderita}

Formation. The type section for this member is defined at the north-west of La Cortaderita creek, between $31^{\circ} 37^{\prime} 46^{\prime \prime} \mathrm{S} / 69^{\circ} 26^{\prime} 12^{\prime \prime} \mathrm{W}$ and $31^{\circ} 37^{\prime} 46^{\prime \prime} \mathrm{S} / 69^{\circ} 26^{\prime} 9,3^{\prime \prime} \mathrm{W}$, although it can also be recognized at the Cementerio and La Tinta creeks. The base of the Don Raúl Member is located at the top of the last thick lens of stacked channelized coarse bodies of the Barreal Formation. The upper limit of the member corresponds to the beginning of a series of laminated, fine-grained, pink-red to purplish sandstones that characterizes the La Emilia Member. The thickness of Don Raúl Member changes along the depocenter, from $25 \mathrm{~m}$ at the type locality to 35 $\mathrm{m}$ at the La Tinta creek and as much as $85 \mathrm{~m}$ towards the south-west of La Cortaderita creek (Figs. 6.1; 8).

This member consists of yellowish cross-stratified conglomerates and sandstones (lithofacies Gh, Gt and St, Table 2) in lenticular bodies containing pumice clasts and tree trunk moulds, interlayered with greyish massive bentonitic and siltstones, muddy-sandstones (lithofacies Fm and Fr, Table 2), and greenish bentonites (lithofacies T, Table 2). These fine-grained facies are highly bioturbated with soils, root traces, and host abundant plant fossil remains (impressions-compressions leaves and permineralized tree-trunks, several of them in life position). The lithofacies are arranged in at least four fining-upward cycles in this unit (Fig. 8).

The sandy and conglomeratic channels possess a staking arrangement, showing deep erosive bases (lithofacies Gh, Gt, St, and Sp; Fig. 6.3). Floodplains are characterized by crevasse channels, crevasse splays, and vertical accretion fine sediments. Lenticular crevasse channels generally do not exceed one meter thickness (lithofacies Ss, St, and Sm). Crevasse splays are less than 1 meter thick with a flat base and convex-up surface, and are distinguished by heterolithic bedding (lithofacies Sh and Fsm). Floodplain fines are recognized by the dominance of fine siltstone, mudstone, and claystone deposits, with evidence of paedogenic alteration (lithofacies $\mathrm{Fr}$ and $\mathrm{Fm}$ ). This succession is also interlayered with abundant both primary and reworked ash fall beds (lithofacies T) (Fig. 6.4).

The palaeosols at Don Raúl Member are characterized by redoximorphic features, bioturbation, roots, slickensides, and nodules (Fig. 6.7). They have been classified as gleyed Vertisol (Mack et al., 1993). Palaeosol X-ray diffraction analyses provided a soil composition of: quartz $86 \%$, clays $12 \%$, and feldspars traces with plagioclases less than $2 \%$. The high proportion of quartz could be related to the high volcaniclastic input. The clay fraction is as follows: kaolinite (56\%), smectite (42\%), interstratified illite/ smectite $(2 \%)$; these values point out to a very low diagenetic alteration after final burial.

On the basis of this facies arrangement, we interpret that the Don Raúl Member of Cortaderita Formation corresponds to mid-high sinuosity anastomosed fluvial system, with gravel and sandy amalgamated channels, and well-developed floodplains, where temporal ponds or lakes would have developed.

\subsubsection{La Emilia Member of the Cortaderita}

Formation. We observed a transitional passage between the Don Raúl and La Emilia members, which is defined here as the contact located at the beginning of the first laminated, fine-grained, pink-red to purplish sandstones. Detailed sedimentological studies at the La Cortaderita and La Tinta creeks does not show any evidence of large depositional or temporal gap in the boundary between the two members, although contrasting colours and palaeoenvironmental changes can be recognized between them.

The type section for the La Emilia Member is situated between $31^{\circ} 37^{\prime} 46^{\prime \prime} \mathrm{S} / 69^{\circ} 26^{\prime} 9,3^{\prime \prime} \mathrm{W}$ and $31^{\circ} 37^{\prime} 45,24^{\prime \prime} \mathrm{S} / 69^{\circ} 26^{\prime} 3,37^{\prime \prime} \mathrm{W}$ north-west of the La Cortaderita creek (Fig. 3). The upper boundary of this member is considered to be at the top of the Cortaderita Formation and the beginning of the red beds of the Cepeda Formation (through an erosive unconformity). The thickness of this member varies from $65 \mathrm{~m}$ at its type locality of La Cortaderita creek to $90 \mathrm{~m}$ towards the south-east of the same creek and decreasing to $55 \mathrm{~m}$ at the La Tinta creek (Figs. 6.1; 8).

The La Emilia Member begins with trough crossstratified, medium-grained, pink to purplish sandstones (lithofacies St, Table 2), and follows with massive and laminated fine-grained pink to purplish sandstones, and massive and laminated grey siltstones and claystones, with abundant tuffaceous clasts, paedogenetic features, 


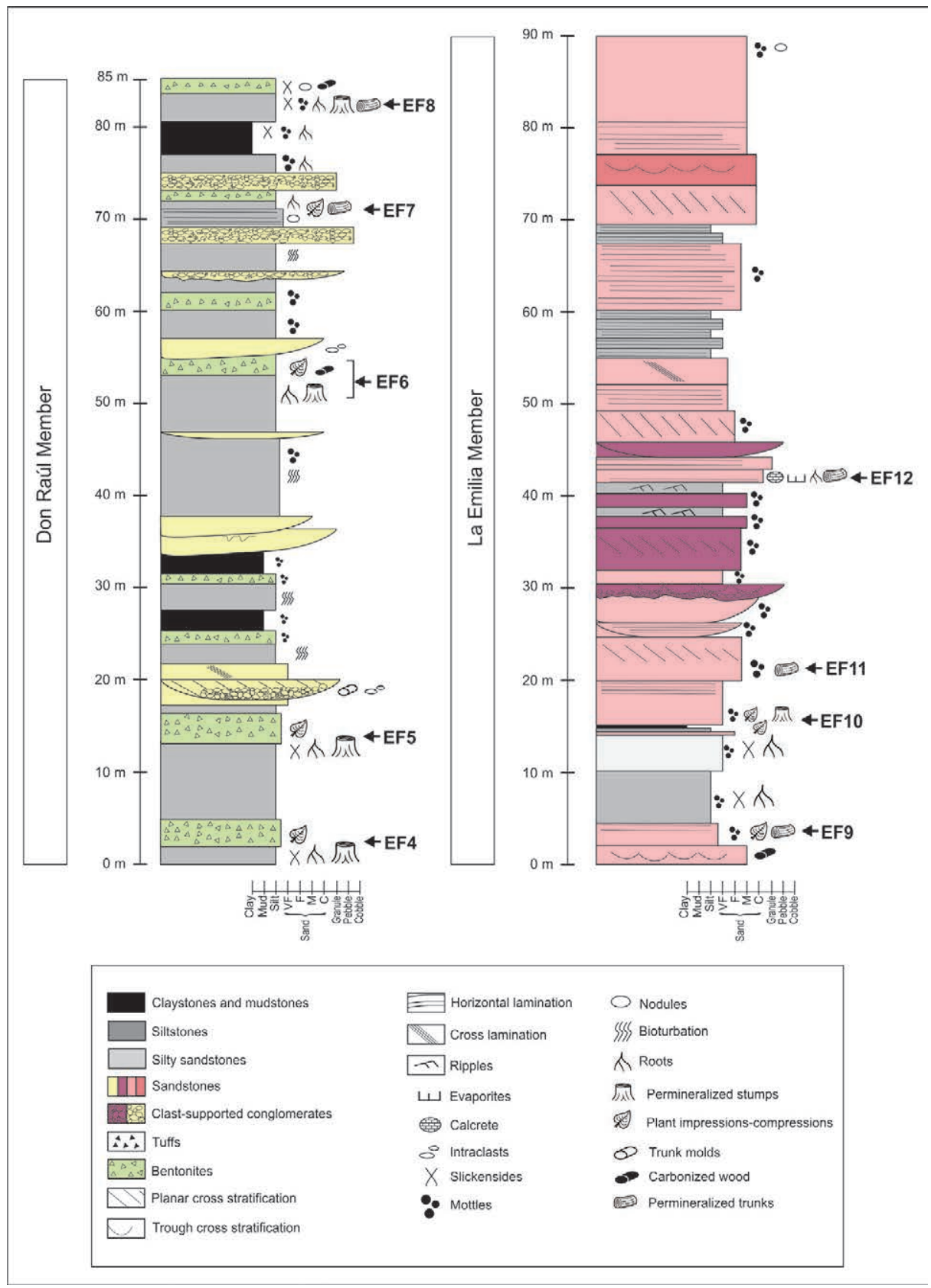

FIG. 8. General stratigraphic log of Don Raúl Member and the La Emilia Member of Cortaderita Formation. EF4 to EF12 indicate fossiliferous strata considered in this study.

and abundant plant impressions (lithofacies Smp, Sl, FmFl, Table 2). The succession follows with cross-laminated pink and reddish-brown fine-grained sandstones and orange granule-conglomerates, bearing numerous permineralized tree-trunks, several of them in life position (Fig. 8).
Along the member's section, channel and floodplain deposits with abundant tuffaceous sediments are recognized. Two different types of channels are observed: lenticular and sheet-like.The first one has an erosive base and usually exhibits a multi-storey arrangement, containing cross-stratified 
conglomerates and sandstones (lithofacies Gt, St and $\mathrm{Sp})$. In contrast, sheet-like channels have simple extensive tabular bodies and are composed mainly of laminated sandstones (lithofacies Sl and Sh).

Floodplains are represented by sheet-flood deposits, overbank fine sediments, and palaeosols. Sheetflood deposits may correspond to overflow episodic events, which are probably related to ash fall occurrences, as interpreted on the basis of the high proportion of tuffaceous clasts. They are characterized by medium to fine horizontal and ripple laminated sandstones and mudstones (lithofacies Sl, $\mathrm{Sr}$ and $\mathrm{Fl}$ ). Overbank fine sediments are represented by fine epiclastics facies with high pyroclastic composition (Fr, Fm). They are very restricted in the lower part of the member, and become better developed towards the upper part of the unit, where they become interlayered with sandy channelized bodies, representing a change in the sinuosity of the fluvial system.

Palaeosols developing in coarse reddish massive sandstones (lithofacies Smp) show diverse paedogenic structures, such as redoximorphic features, bioturbation, rhizoliths, permineralized roots, evaporites, and calcretes, which allow us in interpreting them as Calcisols (Mack et al., 1993) (Fig. 6.8). Palaeosol X-ray diffraction analyses provide the following composition: quartz (75\%), clays $(25 \%)$, feldspars (2.5\%), and plagioclases $(2.5 \%)$, while the clay fraction has smectite (100\%) and clinoptilolite (ceolite) traces. The calcrete levels (lithofacies P) are composed of calcite ( $85 \%$ ) and quartz $(15 \%)$.

Based on the facies arrangement, we interpret that the La Emilia Member corresponds to a high- energy sandy braided fluvial system (sensu Miall, 1996), whose sinuosity increases towards the top.

\subsection{Upper sequence of the Sorocayense Group}

The third tectosedimentary sequence overlies the middle Sequence through a conspicuous angular unconformity, which marks the beginning of the typical red beds of the Cepeda Formation (Figs. 9.1, 10). The whole sequence is coincident with the boundaries of the already defined Cepeda Formation (Groeber and Stipanicic, 1953).

\subsubsection{Cepeda Formation}

The Cepeda Formation is exposed at the Cementerio, Cepeda, Cortaderita, La Tinta, and Un Salto creeks. This unit always overlies Triassic sedimentary rocks, except towards the south of the Un Salto creek where an reverse fault can be observed in the contact between Triassic and the folded Palaeozoic rocks (Fig. 3). The thickness of the Cepeda Formation ranges between 100 and $150 \mathrm{~m}$. Its base is characterized by clast-supported oligomictic conglomerates (lithofacies Gh), with orange tuffaceous sandy matrix and abundant intraclasts of Triassic sandstones (reworked from previous units), pyroclasts, and other volcanic clasts. Basal conglomerates also have permineralized wood fragments, which were redeposited from the Cortaderita Formation (several of them with evident eroded surfaces). The succession continues with reddish planar cross-stratified pebbly sandstones and fine conglomerates (lithofacies Sp and Gp, Table 2).
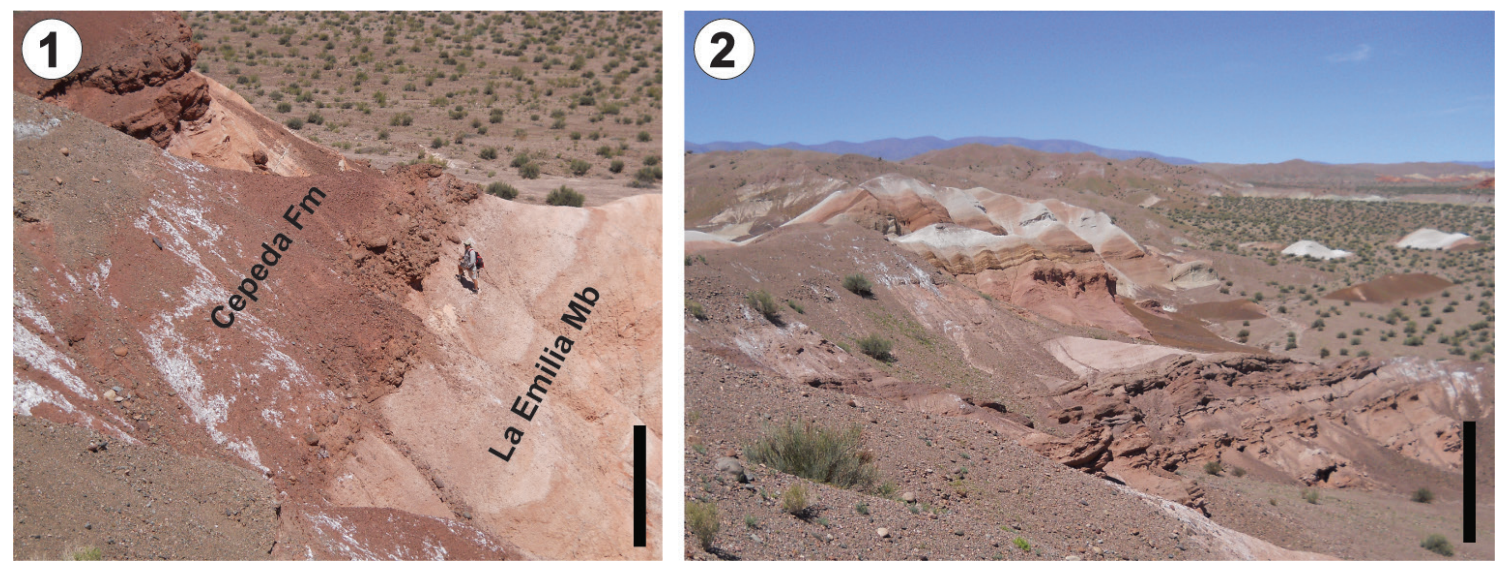

FIG. 9. Cepeda Formation. 1. Contact between La Emilia Member and Cepeda Formation; 2. General view of Cepeda Formation at Cementerio creek. Scale bar: $\mathbf{1}=5 \mathrm{~m} ; \mathbf{2}=10 \mathrm{~m}$ 


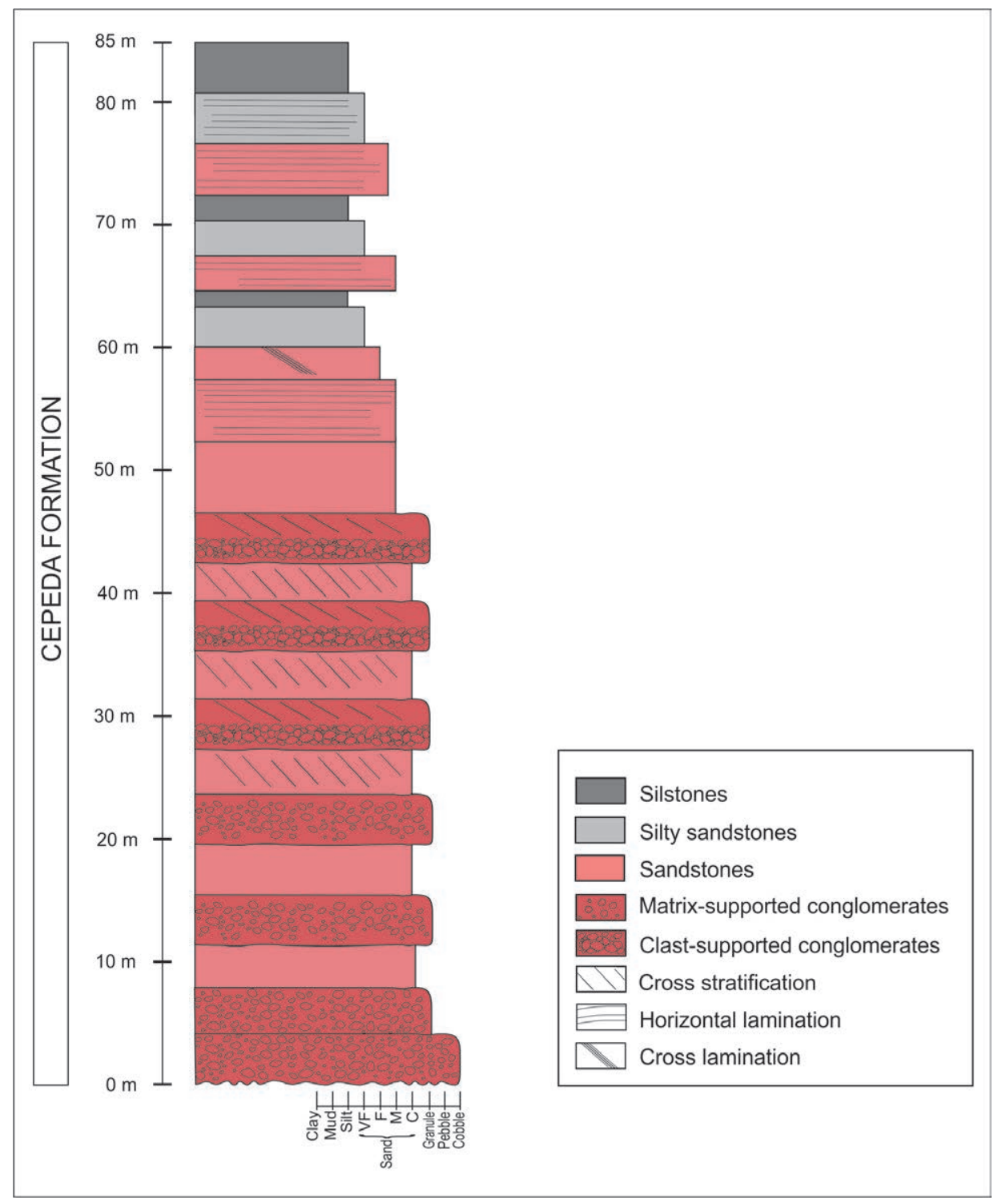

FIG. 10. General stratigraphic log of the Cepeda Formation.

Towards the top of the Cepeda Formation, reddish tabular fine-grained sandstones (Sm, Table 2), horizontal and ripple laminated sandstones (lithofacies Sh and Sr, Table 2), and massive yellowish and greenish tuffaceous siltstones (lithofacies Fm, Table 2) are interlayered (Fig. 9.2; 10).

The lower section of the Cepeda Formation is interpreted as deposited by alluvial systems, with eventual lobes of gravity-flow deposits. The upper section of the Cepeda Formation is inferred as developed by an ephemeral fluvial system, mostly based on the association of tabular sandy bodies with plane-bed flow (critical flow regime; lithofacies $\mathrm{Sh}, \mathrm{Sl}$ and Sm, Table 2) and fine-grained deposits (lithofacies Fm, Table 2).

\section{Fossiliferous strata of the Sorocayense Group}

In the present study, we relocated all historical fosiliferous levels studied by Frenguelli (1948), Bonetti 
(1963), Artabe et al. (1995) and Bodnar (2010), and presented two new fossiliferous strata. Furthermore, new fossil samples as well as new taxa were found in the already identified levels. Therefore, twelve plant fossiliferous strata were recognized. They are represented by impressions-compressions of small axes, leaves and reproductive structures, as well as permineralized branches, trunks and stumps (Table 1; Figs. 7, 8). All the fossiliferous strata (EF) come from the Barreal and Cortaderita formations (middle sequence). Table 1 detailed the correlations between previously described strata and those defined here, and the table 3 summarizes the fossil content of each fossiliferous stratum. The most representative plant fossils are illustrated in figure 11.

The EF1, EF2 and EF3 strata were found at the Barreal Formation. EF1 and EF2 constitute totally new fossil levels, as they consist of permineralized stumps in life position of corystosperms, which are preserved in grey massive siltstones, altered by bioturbation and soil development (lithofacies Fr, Table 2), and covered by bentonites (lithofacies $\mathrm{T}$, Table 2). Furthermore, impressions of equisetalean axes and osmundacean leaves were identified at EF1; and trunk moulds and leaf compressions of undetermined gymnosperms at EF2. On the other hand, the EF3 fossiliferous stratum coincided partially with the NFI level studied by Bonetti (1963), since the fossiliferous horizon found by this author at the La Cortaderita creek (and described as "NFI punto 12 ") is actually located in the Cortaderita Formation, as indicated by Zamuner et al. (2001). Furthermore, we found that the NFII level described by Bonetti for the Cortaderita Formation at the Un Salto creek (and named as"NFII punto 20" and "NFII punto 21 ") is placed in the upper section of the Barreal Formation, and thus both correspond to the EF3 (Table 1). The EF3 stratum preserves abundant plant fossils as impressions-compressions, comprising leaves and reproductive structures of dipteridacean ferns (genera Dictyophyllum, Thaumatopteris and Hausmannia), ginkgoales (e.g., Saportaea spp.), corystospermales (e.g., Zuberia spp., Pteruchus barrealensis, Umkomasia speciosa), gnetales (e.g., Yabeiella spp.), and cycadales (Pseudoctenis fissa), and stems of lycophytes and equisetales in grey claystones, siltstones and sandstones (lithofacies Smp, Fm, Fsm and Fr) interlayered with few lenticular and tabular bodies of massive sandstones and crossstratified fine conglomerates (lithofacies Sm, Gm and Gt). From the fossiliferous strata described by Artabe et al. (1995), only the third one could be identified and located during field trips and is correlated with EF3. For this reason, those levels and the taxa registered in them were not included in the present palaeofloristic analysis.

At the Cortaderita Formation, nine fossiliferous strata were found (EF4 to EF12). The strata from EF4 to EF8 are located in the Don Raúl Member. The EF4 corresponds to the "level 1" of the lower fossiliferous stratum of the Cortaderita Formation from Artabe et al. (1995) (Table 1). It contains permineralized stumps of corystosperms (Rhexoxylon cortaderitaense), equisetalean axes in life position, leaf impressionscompressions of corystosperms (Zuberia feistmanteli, Johnstonia stelzneriana) and dipteridacean ferns (Dictyophyllum spp.) in greyish massive bentonitic and edafized siltstones and muddy-sandstones (lithofacies Fm and Fr). EF5 is correlated with "level 2" of Artabe et al. (1995), and preserves permineralized stumps of Rhexoxylon cortaderitaense (Corystospermales) in life position, leaf impressions-compressions of peltasperms (Scytophyllum bonettiae, Peltaspermum sp.) and cycadales (Pseudoctenis sp. nov.) in greyish massive bentonitic and edafized siltstones (lithofacies Fm and Fr), and greenish bentonites (lithofacies T). "Level 3" from Artabe et al. (1995) is differentiated here in the EF6 and EF7 fossiliferous strata. EF6 is characterized by a remarkably diverse taphocenosis, which is preserved in greyish massive and edafized bentonitic siltstones (lithofacies Fm and Fr) and composed of impressions-compressions of bryophytes, marattialean ferns, leaves of corystosperms (e.g., Dicroidium spp.), peltasperms (genera Scytophyllum, Lepidopteris, Pachydermophyllum), cycadales (Pseudoctenis sp. nov. and Kurtziana cacheutensis), ginkgoales (Ginkgoites waldeckensis and Sphenobaiera spp.), and conifers (Elatocladus planus and Heidiphyllum spp.), together with permineralized stumps and trunks of corystosperms ( $R$. cortaderitaense) and conifers (Juniperoxylon zamunerae). Whereas, EF7 is distinguished by a less diverse taphocenosis but with rather abundant samples, preserved in greyish massive and edafized bentonitic siltstones (lithofacies $\mathrm{Fm}$ and $\mathrm{Fr}$ ). It consists of impressions-compressions of dipteridacean ferns (Dictyophyllum tenuifolium), leaves of corystosperms (e.g., Dicroidium spp.), peltasperms (genera Scytophyllum, Lepidopteris, Pachydermophyllum and cf. Delnortea), ginkgoales (e.g., Baeira cuyana), and conifers (e.g., Elatocladus 

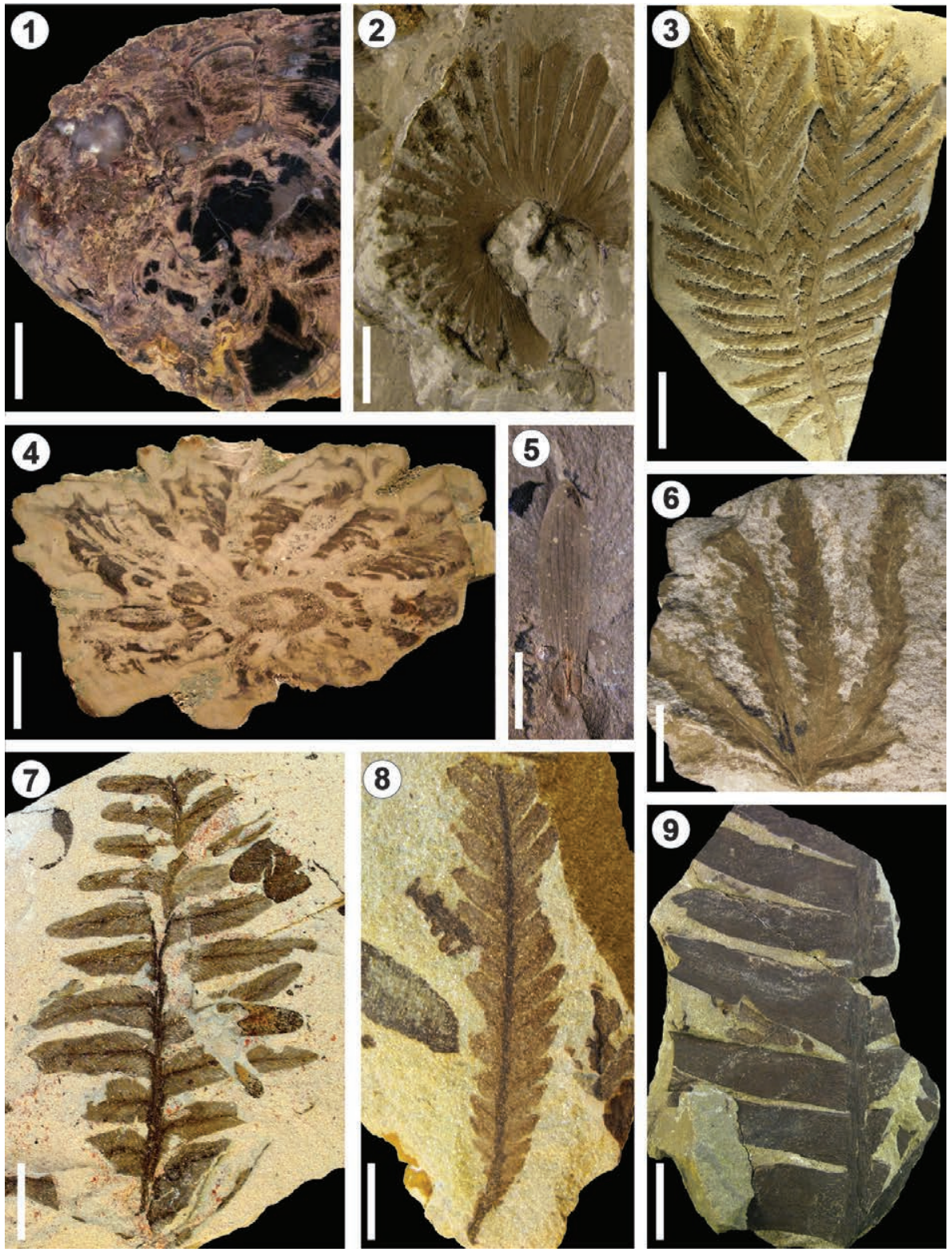

FIG. 11. Paleofloristic elements of the Sorocayense Group at Barreal area. 1. New genus of corystosperm trunk (PBSJ 1053); 2. Saportaea intermedia (BAPb 4284); 3. Zuberia zuberi (LPPB 9520); 4. Rhexoxylon cortaderitaense (CTES-PB 10178); 5. Fraxinopsis andium (BAPb 4206); 6. Dictyophyllum castellanosi (BAPb 6228); 7. Pachydermophyllum papillosum (PBSJ 457); 8. Scytophyllum bonettiae (LPPB 13109); 9. Pseudoctenis sp. nov. (LPPB 13858). Scale bars:1=2 cm; $2=1 \mathrm{~cm} ; \mathbf{3}=7 \mathrm{~cm}$; $\mathbf{4}=2,5 \mathrm{~cm} ; \mathbf{5}=1 \mathrm{~cm} ; \mathbf{6}=2 \mathrm{~cm} ; \mathbf{7}=1 \mathrm{~cm} ; \mathbf{8}=1 \mathrm{~cm} ; \mathbf{9}=2,5 \mathrm{~cm}$.

planus), together with permineralized stumps and trunks of corystosperms $(R$. cortaderitaense) and conifers (Juniperoxylon zamunerae). This fossiliferous stratum corresponds to "NFI punto 12" from Bonetti (1963), originally placed in the Barreal Formation by this author.
EF8 consists of a permineralized forest studied by Bodnar (2010), exclusively constituted by stumps in life position and trunks of corystosperms $(R$. cortaderitaense) preserved in greyish massive bentonitic and edafized siltstones, muddy-sandstones (lithofacies Fm and Fr), and greenish bentonites (lithofacies T). 
In the La Emilia Member, EF9 to EF12 fossiliferous strata were recognized. EF9 is equivalent to the fossil horizon where Frenguelli (1944) found the type material of the corystosperms Zuberia feistmanteli and "Pterorrachis barrealensis" (reinterpreted as a new species of Pteruchus by Bodnar and Beltrán, 2013; Table 3). The fossils are preserved as impressions-compressions in horizontal, laminated, pink medium-grained sandstones. EF10 corresponds to "NFIII punto 32" from Bonetti (1963). The base of this fossiliferous stratum is characterized by leaf impressions of corystosperms (Dicroidium spp.), peltasperms (genera Scytophyllum, Lepidopteris, Pachydermophyllum), cycadales (Kurtziana cacheutensis and Pseudoctenis longipinnata), ginkgoales (Ginkgodium nathorsti and Sphenobaiera spp.), and gnetales (Yabeiella spp.), with an oxide patina preserved in grey and pink fine ripple laminated fine-grained sandstones, siltstones, and claystones (lithofacies $\mathrm{Sl}$ and $\mathrm{Fl}$ ). The top of the EF10 consists of permineralized stumps and trunks (Rhexoxylon cortaderitaense), together with impressions-compressions of very large leaves (Zuberia feistmanteli) of corystosperms, preserved in massive and laminated pink mediumgrained tuffaceous sandstones (lithofacies Sl and Smp). The EF11 fossiliferous stratum host isolated corystosperm permineralized trunks in crossstratified pink sandstones (lithofacies Sp). Finally, the EF12 fossiliferous stratum, which corresponds to "NFIII punto 36" from Bonetti (1963), preserved a permineralized forest comprising Rhexoxylon cortaderitaense in massive and edafized sandstones that are associated with evaporites and calcrete levels (lithofacies Smp and P).

In the Cepeda Formation, we only found reworked permineralized trunks from underlying lithostratigraphic units in clast-supported oligomictic conglomerates (lithofacies Gh). However, Herbst (1995) noted the presence of osmundaceous fern permineralized stems (Millerocaulis stipabonetti) in the lower part of the Cepeda Formation, being the only published description of fossils for that unit.

\section{Discussion and conclusions}

\subsection{Stratigraphy and sedimentology}

From this study, we found clear differences when the Triassic deposits of Barreal are compared with the Hilario and Rincón Blanco depocenters. While the thickness of the column reaches 3000 meters at Rincón Blanco and $1400 \mathrm{~m}$ at Hilario, the Barreal succession is approximately $500 \mathrm{~m}$ thick. The lacustrine systems did not develop at the Barreal depocenter; only temporal pond or lakes were established as a result of periodic waterlog of fluvial floodplains. Otherwise, as explained in the following sections, the lithostratographic units outcropping at Barreal can be well correlated with those from the Hilario and Rincón Blanco areas.

\subsubsection{Basal sequence}

The basal sequence, Cerro Colorado del Cementerio Formation, was described by several previous authors as a Late Paleozoic or Early Triassic succession separated from the Sorocayense Group (Heim, 1945; Zöllner, 1950; Mésigos, 1953; Quartino et al., 1971; López Gamundi and Martínez, 2003) or as the basal part of the Barreal Formation (Stipanicic, 1972, 1979; Damborenea, 1974; Bonati et al., 2008; Tapia Baldis, 2013, Abarzúa, 2016; Rocher et al., 2016). Although Damborenea (1974) included the conglomerates and sandstones of this succession into the Barreal Formation, she considered a Cenozoic age for the ignimbrite beds (section 2). In this work, we proposed to separate this succession in the new unit, Cerro Colorado del Cementerio Formation.

The Cerro Colorado del Cementerio Formation can be correlated with the lower units of the Rincón Blanco Group (Fig. 12), at the north-east of the Rincón Blanco half-graben. Sections 1, 2 and 3 are comparable with the alluvial fan systems of the Ciénaga Redonda Formation (see Barredo and Ramos, 2010; Barredo et al., 2012), although the ignimbrites are more conspicuous and thicker in the Barreal depocenter. Section 4 can be correlated with the fluvial systems of the lower part of Cerro Amarillo Formation. This correlation differs from that proposed by Abarzúa (2016), which compared the basal sequence of the Sorocayense Group (included by the author in Barreal Formation) with the Panul Formation of the Rincón Blanco Group.

Conversely, the correlation resulting in this work is in agreement with Barredo (2012) and Barredo et al. (2012), who defined the first rifting pulse within the half graben evolution (synrift I), which is characterized by alluvial-fluvial and shallow lacustrine deposits, and encompassed the Ciénaga Redonda Formation and 
TABLE 3. DISTRIBUTION OF PLANT TAXA RECORDED IN THE FOSSILIFEROUS STRATA (EF) OF THE SOROCAYENSE GROUP AT BARREAL DEPOCENTER.

\begin{tabular}{|c|c|c|c|c|c|c|c|c|c|c|c|c|}
\hline TAXA & EF1 & EF2 & EF3 & EF4 & EF5 & EF6 & EF7 & EF8 & EF9 & EF10 & EF11 & EF12 \\
\hline \multicolumn{13}{|l|}{ Bryophytes } \\
\hline 1. $\quad$ Thallites $\mathrm{sp} .1$ (gametophyte)* & & & & & & $\mathrm{x}$ & & & & & & \\
\hline 2. $\quad$ Thallites sp. 2 (gametophyte)* & & & & & & $\mathrm{x}$ & & & & & & \\
\hline 3. $\quad$ Muscites sp. (gametophyte)* & & & & & & $\mathrm{x}$ & & & & & & \\
\hline \multicolumn{13}{|l|}{ Lycophytes } \\
\hline 4. $\quad$ Lepidanthium sporiferum (stem) & & & $\mathrm{x}$ & & & & & & & & & \\
\hline 5. $\quad$ cf. Lycopodites (stem)* & & & $\mathrm{x}$ & & & & & & & & & \\
\hline \multicolumn{13}{|l|}{ Sphenophytes (Equisetales) } \\
\hline 6. $\quad$ Phylloteca australis (stem) & & & $\mathrm{x}$ & & & & $\mathrm{x}$ & & & & & \\
\hline Neocalamites sp. (stem) & & & $\mathrm{x}$ & $\mathrm{x}$ & & & & & & & & \\
\hline 8. Equisetites fertilis (stem) & $\mathrm{x}$ & & $\mathrm{x}$ & & & & $\mathrm{x}$ & & & & & \\
\hline \multicolumn{13}{|l|}{ Ferns (Asterothecaceae) } \\
\hline 9. Cf. Rienitsia arrondiana (leaf)* & & & & & & $\mathrm{x}$ & & & & & & \\
\hline \multicolumn{13}{|l|}{ Ferns (Osmundaceae) } \\
\hline 10. Cladophlebis mendozaensis (leaf) & & & & & & & $\mathrm{x}$ & & & & & \\
\hline 11. Cladophlebis sp. (leaf) & $\mathrm{x}$ & & & & & & $\mathrm{x}$ & & & & & \\
\hline \multicolumn{13}{|l|}{ Ferns (Dipteridaceae) } \\
\hline 12. Dictyophyllum castellanosii (leaf) & & & $\mathrm{x}$ & & & & & & & & & \\
\hline 13. Dictyophyllum tenuifolium (leaf) & & & & & & & $\mathrm{x}$ & & & & & \\
\hline 14. Dictyophyllum menendezi (leaf) & & & & $\mathrm{x}$ & & & & & & & & \\
\hline 15. Thaumatopteris barrealensis (leaf) & & & $\mathrm{x}$ & & & & & & & & & \\
\hline 16. Hausmania faltisiana (leaf) & & & $\mathrm{x}$ & & & & & & & & & \\
\hline \multicolumn{13}{|l|}{ Ferns (Dicksoniaceae) } \\
\hline 17. Coniopteris harringtoni (leaf) & & & $\mathrm{x}$ & & & & & & & & & \\
\hline 18. C. walkoni (leaf) & & & $\mathrm{x}$ & & & & & & & & & \\
\hline \multicolumn{13}{|l|}{ Seed ferns (Corystospermaceae) } \\
\hline 19. cf. Dicroidium argenteum (leaf)* & & & & & & $\mathrm{x}$ & & & & & & \\
\hline 20. $\quad$ Dicroidium crassum (leaf) & & & & & & & $\mathrm{x}$ & & & & & \\
\hline 21. D. dubium (leaf)* & & & & & & $\mathrm{x}$ & $\mathrm{x}$ & & & & & \\
\hline 22. $\quad$ Dicroidium lancifolium (leaf) & & & $\mathrm{x}$ & & & $\mathrm{x}$ & $\mathrm{x}$ & & & $\mathrm{x}$ & & \\
\hline 23. Dicroidium odontopteroides (leaf) & & & $\mathrm{x}$ & & & $\mathrm{x}$ & $\mathrm{x}$ & & & $\mathrm{x}$ & & \\
\hline 24. Johnstonia coriacea (leaf) & & & $\mathrm{x}$ & & & & & & & & & \\
\hline 25. J. stelzneriana (leaf) & & & $\mathrm{x}$ & $\mathrm{x}$ & & & & & & & & \\
\hline 26. Xylopteris argentina (leaf) & & & $\mathrm{x}$ & & & & $\mathrm{x}$ & & & & & \\
\hline 27. X. elongata (leaf) & & & $\mathrm{x}$ & & & & & & & & & \\
\hline 28. Zuberia barrealensis (leaf) & & & $\mathrm{x}$ & & & & & & & & & \\
\hline 29. Z. feistmantelii (leaf) & & & & $\mathrm{x}$ & & & & & $\mathrm{x}$ & $\mathrm{x}$ & & \\
\hline 30. Z. papillata (leaf) & & & $\mathrm{x}$ & & & $\mathrm{x}$ & & & & & & \\
\hline 31. Z. zuberi (leaf) & & & $\mathrm{x}$ & & & $\mathrm{x}$ & $\mathrm{x}$ & & & & & \\
\hline 32. Rhexoxylon cortaderitaense (trunk) & & & & $\mathrm{x}$ & $\mathrm{x}$ & $\mathrm{x}$ & $\mathrm{x}$ & $\mathrm{x}$ & $\mathrm{x}$ & $\mathrm{x}$ & $\mathrm{x}$ & $\mathrm{x}$ \\
\hline 33. $\quad$ New genus (trunk)* & $\mathrm{x}$ & $\mathrm{x}$ & & & & & & & & & & \\
\hline 34. Pteruchus barrealensis (pollen organ) & & & $\mathrm{x}$ & & & & & & & & & \\
\hline 35. $\quad$ Pteruchus sp. nov.* (pollen organ) & & & & & & & & & $\mathrm{x}$ & & & \\
\hline 36. Umkomasia speciosa (ovulate organ) & & & $\mathrm{x}$ & & & & & & & & & \\
\hline 37. U. macleani (ovulate organ) & & & & $\mathrm{x}$ & & & & & & & & \\
\hline \multicolumn{13}{|l|}{ Seed ferns (Peltaspermaceae) } \\
\hline 38. $\quad$ Pachydermophyllum papillosum (leaf)* & & & & & & $\mathrm{x}$ & $\mathrm{x}$ & & & $\mathrm{x}$ & & \\
\hline 39. P. praecodillerae (leaf) & & & $\mathrm{x}$ & & & & $\mathrm{x}$ & & & & & \\
\hline 40. Scytophyllum argentinum (leaf)* & & & & & & & & & & $\mathrm{x}$ & & \\
\hline 41. S. bonettiae (leaf) & & & & & $\mathrm{x}$ & $\mathrm{x}$ & $\mathrm{x}$ & & & $\mathrm{x}$ & & \\
\hline 42. Lepidopteris stormbergensis (leaf)* & & & & & & & $\mathrm{x}$ & & & $\mathrm{x}$ & & \\
\hline 43. cf. Delnortea abbottiae (leaf)* & & & & & & & $\mathrm{x}$ & & & & & \\
\hline 44. Peltaspermun sp. (ovulate organ) & & & & & $\mathrm{x}$ & & & & & & & \\
\hline
\end{tabular}


table 3 continued.

\begin{tabular}{|c|c|c|c|c|c|c|c|c|c|c|c|c|}
\hline $\begin{array}{r}\text { TAXA } \\
\end{array}$ & EF1 & EF2 & EF3 & EF4 & EF5 & EF6 & EF7 & EF8 & EF9 & EF10 & EF11 & EF12 \\
\hline \multicolumn{13}{|l|}{ Seed ferns (Kannaskoppiaceae) } \\
\hline 45. Rochipteris copiapensis (leaf)* & & & $\mathrm{x}$ & & & & & & & & & \\
\hline 46. $\quad$ R. cuneata (leaf)* & & & $\mathrm{x}$ & & & & & & & & & \\
\hline 47. R. cyclopteroides (leaf)* & & & $\mathrm{x}$ & & & & & & & & & \\
\hline \multicolumn{13}{|l|}{ Cycadales } \\
\hline 48. $\quad$ Kurtziana cacheutensis (leaf) & & & & & & $\mathrm{x}$ & & & & $\mathrm{x}$ & & \\
\hline 49. Pseudoctenis anomozamoides (leaf) & & & & & & & $\mathrm{x}$ & & & & & \\
\hline 50. P. barrealensis (leaf) & & & & & & & $\mathrm{x}$ & & & & & \\
\hline 51. P. ctenophylloides (leaf) & & & & & & & & & $\mathrm{x}$ & & & \\
\hline 52. P. falconeriana (leaf) & & & & & & & $\mathrm{x}$ & & & & & \\
\hline 53. $\quad$ P. fissa (leaf) & & & $\mathrm{x}$ & & & & & & & & & \\
\hline 54. $\quad$ P. longipinnata (leaf)* & & & & & & & & & & $\mathrm{x}$ & & \\
\hline 55. $\quad$ Pseudoctenis sp. nov.(leaf)* & & & & & $\mathrm{x}$ & $\mathrm{x}$ & & & & & & \\
\hline \multicolumn{13}{|l|}{ Ginkgoales } \\
\hline 56. Baeira cuyana (leaf)* & & & $\mathrm{x}$ & & & & $\mathrm{x}$ & & & & & \\
\hline 57. Ginkgodium nathorsti (leaf)* & & & & & & & & & & $\mathrm{x}$ & & \\
\hline 58. $\quad$ Ginkgoites waldeckensis (leaf)* & & & & & & $\mathrm{x}$ & & & & & & \\
\hline 59. $\quad$ Saportaea dichotoma (leaf) & & & $\mathrm{x}$ & & & & & & & & & \\
\hline 60. S. flabellata (leaf) & & & $\mathrm{x}$ & & & & & & & & & \\
\hline 61. S. intermedia (leaf) & & & $\mathrm{x}$ & & & & & & & & & \\
\hline 62. Sphenobaiera argentinae (leaf) & & & $\mathrm{x}$ & & & $\mathrm{x}$ & & & & $\mathrm{x}$ & & \\
\hline 63. $\quad$ S. schenkii (leaf)* & & & & & & $\mathrm{x}$ & & & & & & \\
\hline 64. S. sectina (leaf)* & & & & & & $\mathrm{x}$ & & & & & & \\
\hline 65. S. stormbergensis (leaf) & & & $\mathrm{x}$ & & & & $\mathrm{x}$ & & & $\mathrm{x}$ & & \\
\hline \multicolumn{13}{|l|}{ Conifers (Voltziales) } \\
\hline 66. Heidiphyllum elongatum (leaf) & & & & & & $\mathrm{x}$ & & & & & & \\
\hline 67. H. clarifolium (leaf) & & & & & & $\mathrm{x}$ & & & & & & \\
\hline 68. H. minutifolium (leaf) & & & & & & & $\mathrm{x}$ & & & & & \\
\hline \multicolumn{13}{|l|}{ Conifers (Coniferales) } \\
\hline 69. Elatocladus planus (leafy twigs) & & & & & & $\mathrm{x}$ & $\mathrm{x}$ & & & & & \\
\hline 70. Juniperoxylon zamunerae (trunk) & & & & & & $\mathrm{x}$ & $\mathrm{x}$ & & & & & \\
\hline \multicolumn{13}{|l|}{ Gnetales } \\
\hline 71. Yabeiella brackebuschiana (leaf) & & & $\mathrm{x}$ & & & & & & & $\mathrm{x}$ & & \\
\hline 72. Y. spathulata (leaf) & & & $\mathrm{x}$ & & & & & & & & & \\
\hline 73. $\quad$ Y. wielandi (leaf) & & & $\mathrm{x}$ & & & & & & & & & \\
\hline 74. Y. mareyesiaca (leaf) & & & $\mathrm{x}$ & & & & & & & $\mathrm{x}$ & & \\
\hline 75. Gontriglossa sp. (leaf) & & & $\mathrm{x}$ & & & & & & & & & \\
\hline 76. $\quad$ Fraxinopsis andium (seeds) & & & $\mathrm{x}$ & & & & & & & & & \\
\hline \multicolumn{13}{|l|}{ Gymnosperms incertae sedis } \\
\hline 77. Chiropteris zeilleri (leaf) & & & $\mathrm{x}$ & & & & & & & & & \\
\hline 78. $\quad$ Taniopteris plicatella (leaf) & & & $\mathrm{x}$ & & & & & & & & & \\
\hline 79. T. carruthersi (leaf) & & & $\mathrm{x}$ & & & & & & & & & \\
\hline 80. $\quad$ Linguifolium sp. (leaf) & & & $\mathrm{x}$ & & & & & & & & & \\
\hline 81. Cordaicarpus mackayi (seeds)* & & & & & & & $\mathrm{x}$ & & & $\mathrm{x}$ & & \\
\hline
\end{tabular}

EF1 to EF3 correspond to the Barreal Formation; EF4 to EF8 belong to the Don Raúl Member of Cortaderita Formation, and EF9 to EF12. *=indicates new cites from this work and from Bodnar (2010).

the lower half of the Barreal Formation (equivalent to Cerro Colorado del Cementerio Formation).

Accordingly, the lithological composition and arrangement in the Rincón Blanco and Sorocayense Groups may be similar, not so the thickness, responding to the beginning of the rift geometry. Besides, it comprises the late stages of Gondwanan magmatism, which would correspond to the end of the Choiyoi volcanism (Barredo and Martínez, 2008). In the active margin, there are some volcaniclastic levels 
interlayered (ignimbrites and scarce rhyolitic and lithic tuffs) in the Ciénaga Redonda Formation (Barredo et al., 2012). They correlate in the ramp with alkaline basalt sheets, which are documented in conformity with the sedimentation in the Agua de los Pajaritos (Treo et al., 1985) and El Alcázar formations (Rossa and Mendoza, 1999) in the Hilario depocenter, and with rhyolitic ignimbrites of the Cerro Colorado del Cementerio Formation in the Barreal depocenter.

The environments inferred for sections 3 and 4 may suggest an already open basin with available accommodation space.

\subsubsection{Middle sequence}

On the basis of the recognition of a strong discordance between the Cerro Colorado del Cementerio Formation and the overlying Barreal Formation, and a continuous sedimentological sequence through the Barreal and Cortaderita formations, we differentiate a complete tectosedimentary sequence named, here, as middle sequence. It comprises a basal fanglomerate deposited by an alluvial system, which responds to rapid tectonic change at regional scale, generating the progradation of alluvial fans from West to East direction.

As it was previously described, at the base of the Barreal Formation, a strong erosional surface is recognized, which puts in contact the fanglomerate over sandstones and conglomerates of section 4 of the Cerro Colorado del Cementerio Formation. Although Spalletti (2001b) included this fanglomerate into the Cepeda Formation, most of the works interpreted it as part of the Barreal Formation (e.g., Groeber and Stipanicic, 1953; Bonetti, 1963; Stipanicic, 1972; Bonati et al., 2008; Abarzúa, 2016). This fanglomerate is, here, correlated with the Panul Formation of the Rincón Blanco Group (Fig. 12), both of which are characterized by the development of alluvial fans. Stipanicic (1972) identified similar fanglomerate deposits at the base of the Triassic succession from the Hilario depocenter. We agree with Barredo (1999), Barredo and Ramos (2010), and Barredo et al. (2012), who considered the Panul Formation as the beginning of a second rifting stage or synrift II, interpreting the same for the Barreal fanglomerate.

The alluvial environments evolved to meandering fluvial systems towards the middle part of the Barreal Formation, as the accommodation space of the basin expanded. These fluvial systems are dominated by coarse-grained channels with floodplains. Towards the top of the unit, floodplains become dominant, some with palaeosols and some periodically waterlogged, thereby developing temporal ponds or lakes. This environmental model partly differs from previous interpretations, particularly for the upper part of the Barreal Formation (Spalletti, 2001b; Artabe et al., 2001; Abarzúa, 2016), which had been interpreted as lacustrine systems. The middle and upper part of the Barreal Formation have been correlated with the Agua de Los Pajaritos (interpreted as alluvial and fluvial systems, Abarzúa, 2016) and Monina (interpreted as lacustrine system, Baraldo and Guerstein, 1984; Barredo, 2004; Zamora Valcarce et al., 2008; Abarzúa, 2016) formations at the Hilario depocenter. With respect to the Rincón Blanco Group, the middle and upper part of Barreal Formation can be correlated with the Corral de Piedra Formation (deposited by meandering fluvial systems, according to Barredo et al., 2012) of the Rincón Blanco Group (Fig. 12).

The passage from the Barreal Formation to the Cortaderita Formation is transitional, and the boundary is located at the top of the last thick lens of amalgamated conglomeratic channels (Groeber and Stipanicic, 1953). Bonatti et al. (2008) and Abarzúa (2016) placed the boundary between the two formations approximately $25 \mathrm{~m}$ below the position defined in the original description of Groeber and Stipanicic (1953), and included the fine-grained siliciclastic and pyroclastic beds of the upper part of the Barreal Formation in the Cortaderita Formation. Thus, according to Bonatti et al. (2008) and Abarzúa (2016), the classic fossiliferous strata of the Barreal Formation would be located in the lower part of the Cortaderita Formation. In this work, we maintain the boundary between these units, as proposed by Groeber and Stipanicic (1953) in the original description of the Barreal and Cortaderita formations, which is followed by several authors (Bonetti, 1963; Spalletti, 2001b; Artabe et al., 2001; Bodnar et al., 2018).

On the basis of lithological differences (colour and grain size) and palaeocurrent differences, several researchers have proposed two sections for the Cortaderita Formation (Spalletti, 2001a, b; Spalletti et al., 1999; Artabe et al., 1995, 2001; Zamuner et al., 1999; Morel et al., 2001) and even suggested a regional unconformity between them (Spalletti et al., 1999; Spalletti, 2001a, b; Morel et al., 2003). As stated in the present work, we did not identify this unconformity into the Cortaderita Formation during the field works or in the satellite images, coindicing with other authors who did not 


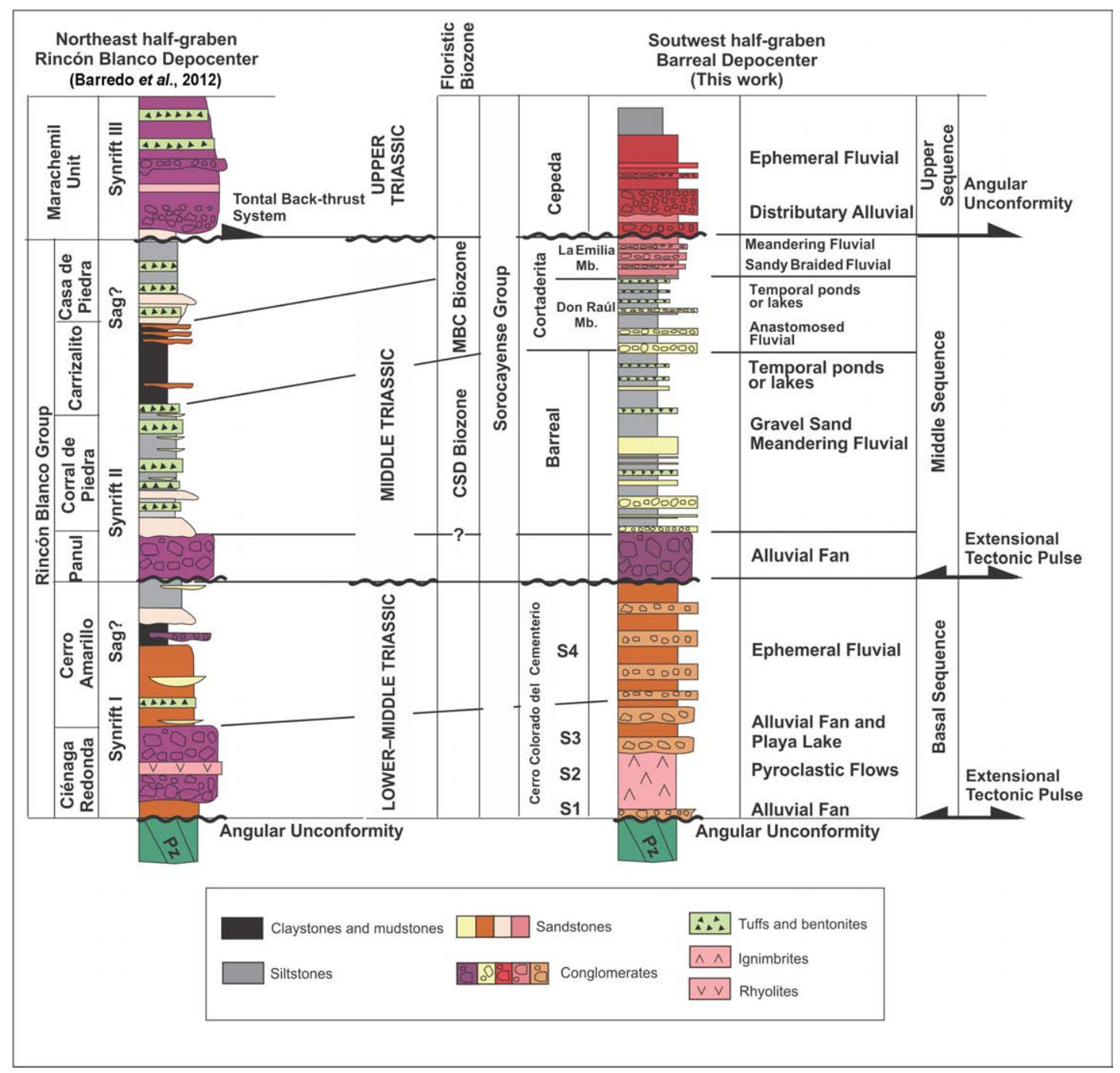

FIG. 12. Proposed correlation of the Triassic units outcropping at Barreal area with the Rincón Blanco Group.

recognize it (e.g., Stipanicic, 2002b; Barredo, 2012; Abarzúa, 2016).

Despite this, we distinguished the lithological variation between the lower and upper sections of this unit and proposed two members. The lower member of the Cortaderita Formation, Don Raúl, exhibits mid-high sinuosity anastomosed conglomeratic channels and sandy amalgamated channels with thick developments of floodplains, which were saturated developing temporal ponds or lakes. While the upper Member, La Emilia, shows a high-energy sandy braided fluvial system that increases its sinuosity grading to a meandering system towards the top. The palaeosols of Don Raúl
Member are of gleyed type, with hydromorphic and vertic properties (Vertisols). With regard to the La Emilia Member, however, the palaeosols recognized are Calcisols. The present interpretation differs from previous works, which proposed that the lower part of the Cortaderita Formation was deposited by holomictic and meromictic lacustrine systems, with several episodes of deltaic progradation (Spalletti, 2001b; Abarzúa, 2016). In the Hilario depocenter, the Don Rául Member is correlated with the Hilario Formation, deposited by sandy fluvial and palustrine systems, (Barredo, 2012; Abarzúa, 2016), and the lower and middle part of the El Alcázar Formation, corresponding 
to lacustrine sedimentation (Barredo, 2012, Abarzúa, 2016). On the other hand, the La Emilia Member is comparable to the uppermost part of the El Alcázar Formation, which was interpreted as a fluvial system with volcaniclastic influence (Barredo, 2012; Drovandi et al., 2016). In the Rincón Blanco Group, the Don Raúl Member is correlated with the Carrizalito Formation (deposited by lacustrine systems, according to Barredo et al., 2012), and the La Emilia Member with the Casa de Piedra Formation (deposited by lacustrine systems, according to Barredo et al., 2012) (Fig. 12).

In accordance with these correlations, the Barreal and Cortaderita formations correspond to the second synrift phase (Synrift II) (Barredo, 2012, Fig. 12). Similarly, as it was described for the Rincón Blanco Group, at the Barreal depocenter, the pyroclastic input was more abundant than that observed in the upper part of Synrift I (represented here by the Cerro Colorado del Cementerio Formation). This is verified by the increase in the levels of ash-fall deposits and reworked tuffs (i.e., bentonites). The great development of floodplains in the upper part of the Barreal Formation and the Don Raúl Member of the Cortaderita Formation, with swamped paleosols, and probably shallow lacustrine facies, would represent the late stages of the rifting phase. Conversely, the braided fluvial systems of the La Emilia Member, with less developed floodplains and well-drained soils, would belong to the postrift stage (Fig. 12).

\subsubsection{Upper sequence}

The upper sequence overlies the middle sequence through a conspicuous angular and erosive unconformity, which marks the beginning of the characteristic red beds of the Cepeda Formation (Fig. 3). Spalletti (2001b) and Spalletti and Barrio (1998) proposed that the Cepeda Formation would have been deposited during a new extensional cycle of the Barreal-Calingasta depocenter. However, there are different opinions about whether the Cepeda Formation also emerges in the Hilario depocenter. Groeber and Stipanicic (1953), as well as Spalletti (2001b) and Abarzúa (2016), assigned the red conglomeratic beds at the top of the Hilario Triassic succession to the Hilario Formation. On the other hand, Barredo (2012) and Tapia Baldis (2013) placed these strata in the Cepeda Formation.

At the Rincón Blanco depocenter, the Cepeda Formation is, in accordance with previous authors
(Barredo, 2004; Barredo 2012; Abarzúa, 2016; Fig. 12), correlated to the Marachemill Formation, which corresponds to alluvial fan, ephemeral stream, and fluvial facies (Barredo et al., 2012).

A return to the extensional tectonic regime (Synrift III) led the deposition of the alluvial fan of the Cepeda Formation lateral equivalent in the Marachemill Unit of the Rincón Blanco depocenter (Barredo, 2012). Synrift III consists of matrix supported conglomerates of alluvial proximal fans, which are composed of volcaniclastics and siliclastics, mostly from the underlying Cortaderita Formation, and tabular sandstone and siltstones that are interpreted as ephemeral rivers.

\subsection{Palaeofloras}

The Cerro Colorado del Cementerio Formation holds only poorly preserved trunk moulds, stem compressions, and very fragmented plant debris. No rich plant levels were found, preventing any taxonomical analyses.

Well-preserved fossil floras were only found in the middle sequence. The number of species (i.e., species richness) of each fossiliferous stratum was entered in a presence/absence matrix, subjected to the "range-through assumption" (absence between the first and last appearance is treated as presence), and plotted as a diversity curve (Fig. 13). The total number of species recorded in the middle sequence reached up to 81. As a whole, the Barreal Formation contains 44 taxa, and the Cortaderita Formation contains 50 taxa. The fossiliferous strata with a higher species richness was EF 3 from the Barreal Formation (43 taxa) and EF 6 from the Don Raúl Member of the Cortaderita Formation (33 taxa). The curve indicates a diminution of the species richness towards the top of the succession.

The Barreal Formation is characterized by taphofloras which are dominated by corystosperms (Zuberia zuberi, an undescribed new genus between the tree forms, and Johnstonia spp. of the shrubby forms). Other important tree/shrub elements are the ginkgoales (Saportaea spp., Baiera cuyana) and cycadales (Pseudoctenis spp.), and ferns of the family Dipteridaceae (Dictyophyllum spp., Thaumatopteris spp., and Hausmania spp.).

The Cortaderita Formation is distinguished by the diversification of corystosperms and peltasperms, the replacement of ginkgoales (the 


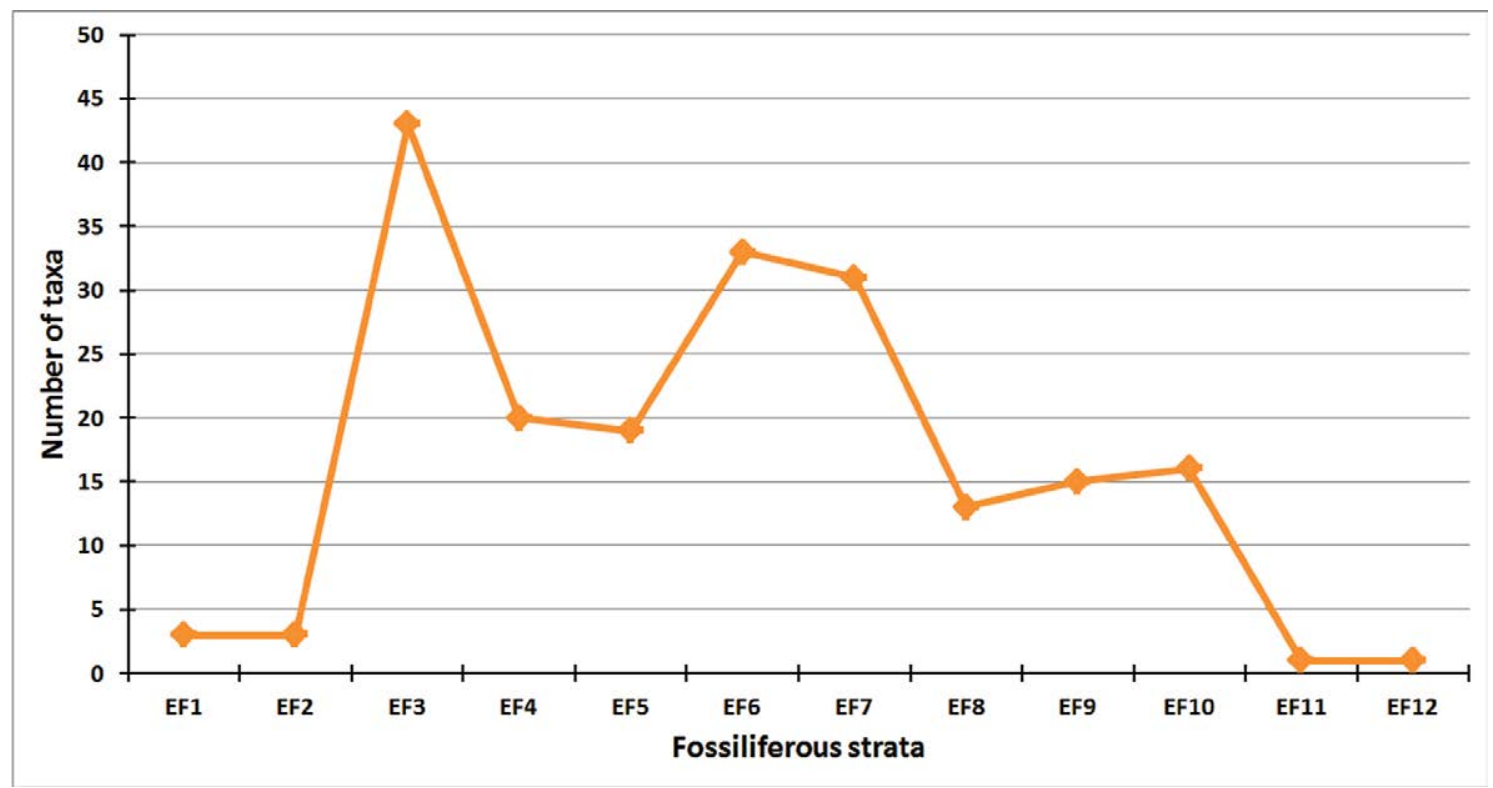

FIG. 13. Diversity (species richness) curve along the stratigraphic column of Sorocayense Group at Barreal area.

genus Saportaea is absent, while predominating the genera Sphenobaiera, Baiera, and Ginkgoites), and the decrease of the Dipteridaceae diversity. The Don Raúl Member hosted highly diverse taphofloras, with petrified forests where the corystosperms (Zuberia feistmantelii, Rhexoxylon cortaderitaense) are the dominant tree forms, and conifers (Elatocladus planus, Juniperoxylon zamunerae) and ginkgoales are subordinated, while the understory forms comprise liverworts (Thallites), mosses (Muscites), ferns (Rienitsia, Dictyophyllum), peltasperms (Scytophyllum, Lepidopteris, Pachydermophyllum), cycadales (Pseudoctenis), and corystosperms (Dicroidium spp.). In the La Emilia Member, the taphocoenosis are less diverse. The petrified forests are exclusively composed of corystosperms as tree forms, and bryophytes and ferns were not recorded.

In spite of the differences between the two members of the Cortaderita Formation, at least 12 taxa recorded in the Don Raúl Member are present in the La Emilia Member (i.e., Dicroidium odontopteroides, D. lancifolium, Rhexoxylon cortaderitaense, Zuberia feistmanteli, Scytophyllum bonettiae, Pachydermophyllum papillosum, Lepidopteris stormbergensis, Cordaicarpus mackayi, Sphenobaiera argentinae, S. stormbergensis, and Kurtziana cacheutensis) (Bodnar, 2010). It means that from the total of 18 taxa recorded in the La Emilia Member, ca. $70 \%$ was already present in the Don Raúl Member; thus, the palaeofloristic differences are mainly a consequence of diminution in diversity.

In the upper sequence (i.e., the Cepeda Formation), the only plant taxon that was found is the tree fern Millerocaulis stipabonetti (Herbst, 1995), preventing a floristic analysis.

In comparison, the fossiliferous levels of the Hilario depocenter (Table 4) are less abundant and less diverse (Ganuza et al., 1998; Zamuner et al., 2001; Drovandi et al., 2016). In this area, the El Alcázar Formation shows the greatest number of taxa, with 33 species, and exhibits more similitude with the taphofloras of the Cortaderita Formation, with 16 species in common (taking into account that the cites of Dictyophyllum sp. and Rhexoxylon sp. from El Alcázar could belong to D. tenuifolium and $R$. cortaderitaense respectively). The Agua de Los Pajaritos Formation presents only 5 plant taxa, but the occurrence of Saportaea dichotoma, an index fossil, both in this unit and Barreal Formation allows relating them. Finally, there are no plant fossils described for the Monina Formation so far; the cited taxa for the Hilario Formation (included in the table 4) would probably come from the uppermost part of the El Alcázar Formation.

When we tried to correlate the palaeontological content of the Sorocayense Group at the Barreal 
TABLE 4. COMPARATIVE TABLE OF THE PLANT TAXA RECORDED IN THE DIFFERENT FORMATIONS OF THE SOROCAYENSE AND RINCÓN BLANCO GROUPS.

\begin{tabular}{|c|c|c|c|c|c|c|c|c|}
\hline TAXA & BARREAL & CORTADERITA & CEPEDA & $\begin{array}{l}\text { A. DE LOS } \\
\text { PAJARITOS }\end{array}$ & $\begin{array}{c}\text { EL } \\
\text { ALCÁZAR }\end{array}$ & HILARIO & $\begin{array}{c}\text { CORRAL } \\
\text { DE PIEDRA }\end{array}$ & $\begin{array}{l}\text { CASA DE } \\
\text { PIEDRA }\end{array}$ \\
\hline Thallites sp. 1 & & $\mathrm{X}$ & & & & & & \\
\hline Thallites sp. 2 & & $X$ & & & & & & \\
\hline Muscites sp. & & $\mathrm{X}$ & & & & & & \\
\hline Lepidanthium sporiferum & $\mathrm{X}$ & & & & & & & \\
\hline Phylloteca australis & $\mathrm{X}$ & $\mathrm{X}$ & & & & & & \\
\hline Neocalamites carrerei & & & & $X$ & $\mathrm{X}$ & $\mathrm{X}$ & & \\
\hline Neocalamites sp. & $\mathrm{X}$ & $\mathrm{X}$ & & & $X$ & $X$ & & $\mathrm{X}$ \\
\hline Equisetites fertilis & $\mathrm{X}$ & $\mathrm{X}$ & & $\mathrm{X}$ & & & & \\
\hline Equisetites quindecidentata & & & & & $\mathrm{X}$ & & & \\
\hline Asterotheca hilariensis & & & & & $X$ & & & \\
\hline Cf. Rienitsia arrondiana & & $X$ & & & & & & \\
\hline Cladophlebis kurtzi & & & & & X & & & \\
\hline C. mendozaensis & & $\mathrm{X}$ & & & $\mathrm{X}$ & & & \\
\hline C. mesozoica & & & & & $\mathrm{X}$ & & & \\
\hline Cladophlebis sp. & $\mathrm{X}$ & $\mathrm{X}$ & & & $\mathrm{X}$ & & & \\
\hline Millerocaulis stipabonetti & & & $\mathrm{X}$ & & & & & \\
\hline Dictyophyllum castellanosii & $\mathrm{X}$ & & & & & & & \\
\hline Dictyophyllum tenuifolium & & $X$ & & & & & & \\
\hline Dictyophyllum menendezi & & $\mathrm{X}$ & & & & & & \\
\hline Dictyophyllum sp. & & & & & $\mathrm{X}$ & & & \\
\hline Thaumatopteris barrealensis & $\mathrm{X}$ & & & & & & & \\
\hline Hausmania faltisiana & $\mathrm{X}$ & & & & & & & \\
\hline Coniopteris harringtoni & $\mathrm{X}$ & & & & & & & \\
\hline C. walkoni & $\mathrm{X}$ & & & & & & & \\
\hline cf. Dicroidium argenteum & & $\mathrm{X}$ & & & & & & \\
\hline Dicroidium crassum & & $\mathrm{X}$ & & & & & & \\
\hline D. dubium & & $\mathrm{X}$ & & & $X$ & & & \\
\hline D. incisum & & & & & & & & $\mathrm{X}$ \\
\hline D. lancifolium & $\mathrm{X}$ & $\mathrm{X}$ & & & $\mathrm{X}$ & & & \\
\hline D. odontopteroides & $\mathrm{X}$ & $X$ & & & $\mathrm{X}$ & & & $\mathrm{X}$ \\
\hline D. pinnis-distantibus & & & & & $\mathrm{X}$ & & & \\
\hline Dicroidium sp. & & & & & $\mathrm{X}$ & & & \\
\hline Johnstonia coriacea & $\mathrm{X}$ & & & & $X$ & & & \\
\hline J. stelzneriana & $\mathrm{X}$ & $\mathrm{X}$ & & $\mathrm{X}$ & & & & \\
\hline Xylopteris argentina & $\mathrm{X}$ & $\mathrm{X}$ & & & & & & \\
\hline$X$. elongata & $\mathrm{X}$ & & & & $\mathrm{X}$ & & & \\
\hline$X$. densifolia & & & & & & & & $\mathrm{X}$ \\
\hline$X$. remotipinnulia & & & & & & & & $\mathrm{X}$ \\
\hline$X$. rigida & & & & & & & & $\mathrm{X}$ \\
\hline$X$. spinifolia & & & & & & & & $\mathrm{X}$ \\
\hline Zuberia barrealensis & $\mathrm{X}$ & & & & & & & \\
\hline Z. feistmantelii & & $\mathrm{X}$ & & & & & & \\
\hline Z. papillata & $\mathrm{X}$ & $\mathrm{X}$ & & & & & & \\
\hline Z. zuberi & $\mathrm{X}$ & $X$ & & $\mathrm{X}$ & $\mathrm{X}$ & & & $\mathrm{X}$ \\
\hline Rhexoxylon cortaderitaense & & $\mathrm{X}$ & & & & & & \\
\hline Rhexoxylon sp. & & & & & $\mathrm{X}$ & & & \\
\hline
\end{tabular}


table 4 continued.

\begin{tabular}{|c|c|c|c|c|c|c|c|c|}
\hline TAXA & BARREAL & CORTADERITA & CEPEDA & \begin{tabular}{|l|} 
A. DE LOS \\
PAJARITOS \\
\end{tabular} & $\begin{array}{c}\text { EL } \\
\text { ALCÁZAR } \\
\end{array}$ & HILARIO & $\begin{array}{c}\text { CORRAL } \\
\text { DE PIEDRA }\end{array}$ & $\begin{array}{l}\text { CASA DE } \\
\text { PIEDRA }\end{array}$ \\
\hline Tranquiloxylon sp. & & & & & $\mathrm{X}$ & & & \\
\hline Pteruchus barrealensis & $\mathrm{X}$ & & & & & & & \\
\hline Pteruchus sp. nov. & & $\mathrm{X}$ & & & & & & \\
\hline Umkomasia speciosa & $\mathrm{X}$ & & & & & & & \\
\hline U. macleani & & $\mathrm{X}$ & & & & & & \\
\hline $\begin{array}{l}\text { Pachydermophyllum } \\
\text { papillosum }\end{array}$ & & $\mathrm{X}$ & & & & & & \\
\hline P. praecodillerae & $\mathrm{X}$ & $\mathrm{X}$ & & & $\mathrm{X}$ & & & \\
\hline Scytophyllum argentinum & & $\mathrm{X}$ & & & & & & \\
\hline S. bonettiae & & $\mathrm{X}$ & & & & & & \\
\hline Lepidopteris stormbergensis & & $\mathrm{X}$ & & & & & & \\
\hline L. madagascariensis & & & & & & & $\mathrm{X}$ & \\
\hline cf. Delnortea abbottiae & & $\mathrm{X}$ & & & & & & \\
\hline \multicolumn{9}{|l|}{ Peltaspermun sp. } \\
\hline Antevsia sp. & & & & & & & $\mathrm{X}$ & \\
\hline Rochipteris copiapensis & $\mathrm{X}$ & & & & & & & \\
\hline R. cuneata & $\mathrm{X}$ & & & & & & & \\
\hline R. cyclopteroides & $\mathrm{X}$ & & & & & & & \\
\hline Sphenopteris sp. & & & & & $\mathrm{X}$ & & & \\
\hline Kurtziana cacheutensis & & $\mathrm{X}$ & & & $\mathrm{X}$ & & & \\
\hline $\begin{array}{l}\text { Pseudoctenis anomozamoi- } \\
\text { des }\end{array}$ & & $\mathrm{X}$ & & & & & & \\
\hline P. barrealensis & & $\mathrm{X}$ & & & & & & \\
\hline P. ctenophylloides & & $\mathrm{X}$ & & & & & & \\
\hline P. falconeriana & & $\mathrm{X}$ & & & & & & \\
\hline P. fissa & $\mathrm{X}$ & & & & & & & \\
\hline \multicolumn{9}{|l|}{ P. longipinnata } \\
\hline Pseudoctenis nov. sp. & & $\mathrm{X}$ & & & & & & \\
\hline Pseudoctenis sp. A & & & & & & & & $\mathrm{X}$ \\
\hline Pseudoctenis sp. B & & & & & & & & $\mathrm{X}$ \\
\hline Pterophyllum sp. & & & & & $\mathrm{X}$ & & & \\
\hline Baeira cuyana & $\mathrm{X}$ & $\mathrm{X}$ & & & $\mathrm{X}$ & & & \\
\hline Baiera sp. & & & & & $\mathrm{X}$ & & & \\
\hline Ginkgodium nathorsti & & $\mathrm{X}$ & & & & & & \\
\hline Ginkgoites waldeckensis & & $\mathrm{X}$ & & & & & & \\
\hline Saportaea dichotoma & $\mathrm{X}$ & & & $\mathrm{X}$ & & & & \\
\hline S. flabellata & $\mathrm{X}$ & & & & & & & \\
\hline Sphenobaiera argentinae & $\mathrm{X}$ & $\mathrm{X}$ & & & $\mathrm{X}$ & & & \\
\hline S. schenkii & & $\mathrm{X}$ & & & & & & \\
\hline S. sectina & & $\mathrm{X}$ & & & & & & \\
\hline S. stormbergensis & $\mathrm{X}$ & $\mathrm{X}$ & & & $\mathrm{X}$ & & & \\
\hline Czekanowskia sp. & & & & & $\mathrm{X}$ & & & \\
\hline Heidiphyllum elongatum & & $\mathrm{X}$ & & & $\mathrm{X}$ & & & \\
\hline H. clarifolium & & $\mathrm{X}$ & & & & & & \\
\hline H. minutifolium & & $\mathrm{X}$ & & & & & & \\
\hline Elatocladus planus & & $\mathrm{X}$ & & & & & & \\
\hline Juniperoxylon zamunerae & & $\mathrm{X}$ & & & & & & \\
\hline Yabeiella brackebuschiana & $\mathrm{X}$ & $\mathrm{X}$ & & & $\mathrm{X}$ & & & \\
\hline
\end{tabular}


table 4 continued.

\begin{tabular}{|l|c|l|l|l|c|c|c|c|}
\hline \multicolumn{1}{|c|}{ TAXA } & BARREAL & CORTADERITA & CEPEDA & $\begin{array}{l}\text { A. DE LOS } \\
\text { PAJARITOS }\end{array}$ & $\begin{array}{c}\text { EL } \\
\text { ALCÁZAR }\end{array}$ & HILARIO & $\begin{array}{c}\text { CORRAL } \\
\text { DE PIEDRA }\end{array}$ & $\begin{array}{c}\text { CASA DE } \\
\text { PIEDRA }\end{array}$ \\
\hline Y. spathulata & $\mathrm{X}$ & & & & & & & \\
\hline Y. wielandi & $\mathrm{X}$ & & & & & & \\
\hline Y. mareyesiaca & $\mathrm{X}$ & $\mathrm{X}$ & & & $\mathrm{X}$ & & & \\
\hline Gontriglossa sp. & $\mathrm{X}$ & & & & & & & \\
\hline Fraxinopsis andium & $\mathrm{X}$ & & & & & & & \\
\hline Chiropteris zeilleri & $\mathrm{X}$ & & & & & & & \\
\hline Taniopteris plicatella & $\mathrm{X}$ & & & & & & & \\
\hline T. carruthersi & $\mathrm{X}$ & & & & & & & \\
\hline Taeniopteris sp. & & & & & $\mathrm{X}$ & & $\mathrm{X}$ & \\
\hline Linguifolium arctum & & & & & $\mathrm{X}$ & & & \\
\hline Linguifolium sp. & $\mathrm{X}$ & & & & & & & \\
\hline Cordaicarpus mackayi & $\mathrm{X}$ & $\mathrm{X}$ & & & & & & \\
\hline
\end{tabular}

depocenter with the Rincón Blanco Group, we encountered some inconveniences. The Rincón Blanco Group preserves scarce megafossil plant remains (Table 4). Only the Corral de Piedra and Casa de Piedra formations bear megafloras. The Casa de Piedra Formation shows some similitude with both the Barreal and Cortaderita formations, as it contains the leaf species Dicroidium odontopteroides and Zuberia zuberi (Ottone, 2006). On the other hand, the Rincón Blanco Group preserves palynofloras in the Corral de Piedra, Carrizalito, and Casa de Piedra formations (Ottone and Rodríguez Amenábar, 2001; Rodríguez Amenábar and Ottone, 2003), while the Sorocayense Group has not preserved palynomorphs so far. Besides, in the Corral de Piedra Formation, Late Triassic vertebrates are represented by a quite diverse association of tetrapod tracks and trackways, which are assigned to crurotarsal archosaurs, dinosaurs, and therapsids (Marsicano and Barredo, 2004). In the Sorocayense Group vertebrate fossils were not found.

In spite of the differences, the taphofloras of the Barreal, Hilario, and Rincón Blanco indicate that the plant palaeocommunities were similar, where the main components were corystosperms, such as arboreal (Zuberia) and shrubby forms (Dicroidium, Xylopteris), peltasperms (Lepidopteris, Pachydermophyllum), and cycads (Pterophyllum, Pseudoctenis).

\subsection{Palaeoclimatic considerations}

The playa lake and ephemeral fluvial systems inferred from the basal sequence would have developed under arid to semi-arid climates.
The palaeosols and the palaeofloras described in the middle sequence provide an idea of the climatic evolution during the Middle Triassic in the Barreal area. The taphocoenosis found in the Barreal and Cortaderita formations were dominated by corystosperms, with conifers, cycadales and peltasperms as subordinate forms. All these groups present xeromorphic features (evergreen habit, thick cuticles, sunken stomata, secretory cavities, successive cambia, and common vegetative reproduction), which suggests that dry conditions are maintained over time. However, the occurrence of lycophytes in the upper part of the Barreal Formation (Beltrán et al., 2018), and mosses and hornworts in the Don Raúl Member of the Cortaderita Formation denote more humid episodes (Bodnar 2010; Bodnar et al., 2018). Together with this, the presence of vertisols and dipterid ferns in the Barreal Formation and the Don Raúl Member of the Cortaderita Formation indicate a seasonal climate. Based on the restricted geographical occurrence of Dipteris today, fossil representatives of the Dipteridaceae are often regarded as reliable indicators of humid, warm-temperate to subtropical climatic conditions (e.g., Barale, 1990; Van Konijnenburg-van Cittert, 2002). Moreover, Cantrill (1995) noted the broadly congruent distribution of fossil Dipteridaceae with inferred patterns of high storminess and seasonal intense rainfall (monsoonal climates). The dipterid ferns found in the Barreal and Cortaderita formations have relatively small leaves, which may suggest that the humidity was not optimal for the development of the typical large leaves of the extant Dipteris (Bodnar et al., 2018). 
Finally, the presence of Hausmannia in the Barreal Formation, a taxon considered to have adapted to more stress-related environments and more arid circumstances (Van Konijnenburg-van Cittert, 2002; Stockey et al., 2006), supports the conclusion of sub-humid seasonal subtropical palaeoclimates.

The plant diversity decreases in the La Emilia Member, which indicates an intensification of dry palaeoclimatic conditions, particularly supported by the presence of calcretes, well drained palaeosols, and absence of bryophytes and ferns. Following Bodnar (2010), we suggest a semi-arid seasonal subtropical palaeoclimate for this part of Cortaderita Formation. The calcisols are typical soils of seasonal arid to semi-arid climates, with limited water supply (Mack et al., 1993; Tabor et al., 2008; Tabor and Myers, 2015).

The sedimentary environments of the upper sequence would have evolved under arid or semiarid climates; however, the presence of the fern Millerocaulis in the Cepeda Formation would denote at least local humid conditions.

This palaeoclimatic interpretation coincides with the inferences made for the Rincón Blanco Group (Barredo and Ramos, 2010; Barredo et al., 2012), with an increase in humidity in the Corral de Piedra, Carrizalito and Casa de Piedra formations, and a return to dry conditions in the Marachemill Formation.

\subsection{Age and biostratigraphic considerations}

According to the correlation with the Rincón Blanco Group, the basal sequence would have deposited during late Early Triassic to early Middle Triassic.

The middle sequence was placed in the Barrealian and Cortaderitian stages in the chronostratographic proposal of Spalletti et al. (1999), which ranged from the late Early Triassic to the early Late Triassic. On the basis of the palaeofloristic content, the same authors proposed a biostratigraphic scheme, where the flora of the Barreal Formation was assigned to early Middle Triassic CSD Biozone (Dictyophyllum castellanosii, Johnstonia stelzneriana, Saportaea dichotoma), the lower section of the Cortaderita Formation (here Don Raúl Member) was assigned to late Middle Triassic MBC Biozone (Yabeiella mareyesiaca, Scytophyllum bonettiae, Rhexoxylon (=Protophyllocladoxylon) cortaderitaense), and the upper section of the Cortaderita Formation (here La Emilia Member) was assigned to the middle Late
Triassic OL Biozone (Dicroidium odontopteroides, Dicroidium lancifolium) (Spalletti et al., 1999; Morel et al., 2003). In summary, according to these authors, the Barreal Formation would correspond to the early Middle Triassic (Anisian stage from the International Chronostratigraphic Chart, Cohen et al., 2013), Don Raúl Member would be late Middle Triassic in age (Ladinian stage from the International Chronostratigraphic Chart, Cohen et al., 2013), and La Emilia Member would have deposited during the middle Late Triassic (late Carnian stage from the International Chronostratigraphic Chart, Cohen et al., 2013). Spalletti et al. (1999) and Morel et al. (2003) proposed an important hiatus in the order of $c a .9 \mathrm{Ma}$. between the two members of the Cortaderita Formation.

Nevertheless, the taphofloras studied in this work show that there are no significant palaeofloristic differences between the two members of the Cortaderita Formation, denoting a temporal continuity in the palaeofloristic evolution and an absence of important hiatus. Both members have diagnostic elements of MBC biozone (i.e., Rhexoxylon cortaderitaense, Scytophyllum bonettiae, Zuberia feistmanteli and Kurtziana cacheutensis (Bodnar, 2008, 2010). These taxa are considered as index fossil: $R$. cortaderitaense and Scytophyllum bonettiae have a brief biochron restricted to the Middle Triassic; while Z. feistmanteli and $K$. cacheutensis are particularly abundant in the late Middle Triassic (Spalletti et al., 1999; Morel et al., 2001). As a result, it can be determined that no significant temporal hiatus exists; and that both Don Raúl and La Emilia members are more accurately assigned to the Middle Triassic (Ladinian stage).

The correlation with the Rincón Blanco Group (Barredo et al., 2012) indicates a late Anisian-early Ladinian age for the Barreal Formation, and a late Ladinian age for the Cortaderita Formation. On its behalf, the upper sequence (i.e., the Cepeda Formation), due to its correlation with the Marachemil Formation (Barredo et al., 2012), and consequently supposed to belong to the Upper Triassic.

\section{Acknowledgments}

We would like to thank E.P. Coturel, A. Artabe, E. Morel and D. Ganuza (Museo de La Plata, Argentina) for help during several seasons of fieldwork. We are also grateful to A. Varela for running the X-ray diffraction analysis and petrographic slides. We thank to G. del Fueyo and L. Lezama (Buenos Aires, Argentina) for the loan of specimens from Palaeobotanical National Collection. 
Finally, we specially acknowledge to Mrs. M. De Luca, the owner of La Elcha Mine (Barreal), and Mr. Zárate and "Danilo", the mine workers. This paper improved significantly due to the remarks and suggestions made by the reviewers Dr. S. Barredo (Instituto Tecnológico de Buenos Aires, Argentina) and Dr. E.G. Ottone (Instituto de Estudios Andinos Don Pablo Groeber, Universidad de Buenos Aires, Argentina). This study was supported by the Agencia Nacional de Promoción Científica y Tecnológica (PICT 2011-2450; PICT 2014-2751) and Universidad Nacional de La Plata (Projects N686, N807).

\section{References}

Abarzúa, F. 2016. Estratigrafía, análisis de cuenca y aspectos exploratorios en el extremo norte de Cuenca Cuyana. Precordillera Occidental y Valle de Calingasta. Tesis Doctoral (Unpublished), Universidad Nacional de San Juan, Facultad de Ciencias Exactas, Físicas y Naturales: 187 p.

Andreis, R. 1981. Identificación e importancia geológica de los Paleosuelos. Universidade Federal do Rio Grande do Sul, Livro-Texto 2: 67 p. Porto Alegre.

Artabe, A.E.; Zamuner, A.B.; Ganuza, D.G.; Spalletti, L.A. 1995. Novedades en la tafoflora triásica de la quebrada de la Cortaderita, Barreal, Provincia de San Juan, Argentina. In Reunión del triásico del Cono Sur, No. 2, Actas 1: 7. Bahía Blanca.

Artabe, A.E.; Morel; E.M.; Spalletti, L.A. 2001. Paleoecología de las floras triásicas argentinas. In El Sistema Triásico de Argentina (Artabe, A.E.; Morel, E.M.; Zamuner, A.B.; editors). Fundación Museo de La Plata "Francisco Pascasio Moreno": 199-225. La Plata.

Baraldo, J.A.; Guerstein, P.G. 1984. Nuevo ordenamiento estratigráfico para el Triásico de Hilario (Calingasta, San Juan). In Congreso Geológico Argentino, No.9, Actas 1: 79-94. San Carlos de Bariloche.

Barale, G. 1990. Les stratégies adaptives chez les végétaux du Trias supérieur au Crétacé inférieur dans l'aire eurosinienne, en relation avec l'évolution du climat. Comptes Rendus de 1'Académie des Sciences 311, Serie II: 265-269.

Barredo, S.P. 1999. El Fanglomerado Panul como unidad diferenciada de la Formación Portezuelo, su importancia en el análisis evolutivo de la subcuenca Rincón Blanco, Provincia de San Juan. In Congreso Geológico Argentino, No. 14, Actas 1: 441-444. Salta.

Barredo, S.P. 2004. Análisis estructural y tectosedimentario de la subcuenca de Rincón Blanco, Precordillera Occidental, provincia de San Juan. Tesis Doctoral
(Unpublished), Universidad de Buenos Aires, Facultad de Ciencias Exactas y Naturales: 325 p.

Barredo, S.P. 2012. Geodynamic and Tectonostratigrafic study of a continental rift: The Triassic Cuyana Basin, Argentina. In Tectonics (Sharkov, E.; editor). Institute of Geology of Ore Deposits, Petrography, Mineralogy and Geochemistry (IGEM), Russian Academy of Sciences: 99-130. Moscow.

Barredo, S.P.; Ramos, V.A. 1997. Los depósitos de Rincón Blanco (Precordillera de San Juan): un rift triásico. In Jornadas sobre Geología de Precordillera, No. 2, Actas 1: 130-135. San Juan.

Barredo, S.P.; Stipanicic, P. 2002. Rincón Blanco (Grupo...). In Léxico Estratigráfico de la Argentina. Triásico 8 (Stipanicic, P.N.; Marsicano, C.A.; editors). Asociación Geológica Argentina Serie "B” (Didáctica y Complementaria): 241-244. Buenos Aires.

Barredo, S.P.; Martínez, A. 2008. Secuencias piroclásticas triásicas intercaladas en la Formación Ciénaga Redonda, Rincón Blanco, San Juan y su vinculación con el Ciclo Magmático Gondwánico del Grupo Choiyoi. In Reunión Argentina de Sedimentología, No. 12, Resúmenes: 39. Buenos Aires.

Barredo, S.P.; Ramos, V.A. 2010. Características tectónicas y tectosedimentarias del hemigraben Rincón Blanco, Cuenca Cuyana: una síntesis. Revista de la Asociación Geológica Argentina 66 (1-2): 133-145.

Barredo, S.P.; Chemale, F.; Ávila, J.N.; Marsicano, C.; Ottone, G.; Ramos V.A. 2012. Tectono-sequence stratigraphy and $\mathrm{U}-\mathrm{Pb}$ zircon ages of the Rincón Blanco Depocenter, northern Cuyo Rift, Argentina. Gondwana Research 21: 624-636.

Beltrán, M.; Bodnar, J.; Coturel, E.P. 2018. Lycopodites (Lycopodiidae, Lycopodiales): un nuevo integrante de las floras triásicas de la Argentina. Revista del Museo Argentino de Ciencias Naturales, n.s. 20 (2): 205-216.

Bodnar, J. 2008. Rhexoxylon cortaderitaense (Menéndez) comb. nov., a species of permineralized stems newly assigned to the Corystospermaceae, from the Triassic of Argentina. Alcheringa 32 (2): 171-190.

Bodnar, J. 2010. La paleoflora triásica de la Formación Cortaderita en la quebrada homónima, Cuenca de Barreal-Calingasta, provincia de San Juan, Argentina. Tesis Doctoral (Unpublished), Universidad Nacional de La Plata, Facultad de Ciencias Naturales y Museo: $283 \mathrm{p}$.

Bodnar, J.; Beltrán, M. 2013. Revisión de las estructuras reproductivas de Corystospermaceae (Spermatopsida) del Triásico Medio del Sudoeste de San Juan. Reunión de Comunicaciones de la Asociación Paleontológica 
Argentina (Córdoba). Ameghiniana 50 Suplemento Resúmenes: R37.

Bodnar, J.; Ruiz, D.; Artabe, A.E.; Morel, E.M.; Ganuza, D.G. 2015. Voltziales y Pinales (=Coniferales) de la Formación Cortaderita (Triásico Medio), Argentina, y su implicancia en la reconstrucción de las coníferas triásicas. Revista Brasileira de Paleontologia 18 (1): 141-160.

Bodnar, J.; Drovandi, J.M.; Morel. E.; Ganuza, D.G. 2018. Middle Triassic dipteridaceae (Gleicheniales, Polypodiopsida) of west-central Argentina and their relationship with palaeoclimatic changes. Acta Palaeontologica Polonica 63 (2): 397-416.

Bonati, S.; Barredo, S.; Zamora Balcarce, G.; Cervera, M.; Kowloksky, E. 2008. Análisis tectosedimentario preliminar del Grupo Barreal, cierre norte de la Cuenca Cuyana, provincia de San Juan. In Congreso de Exploración y Desarrollo de Hidrocarburos, No. 7, Trabajos Técnicos: 409-420. Mar del Plata.

Bonetti, M.I.R. 1963. Contribución al conocimiento de la flora fósil de Barreal, departamento de Calingasta (provincia de San Juan). Tesis Doctoral (Unpublished).,Universidad de Buenos Aires, Facultad de Ciencias Exactas y Naturales: 260 p.

Bonetti, M.I.R. 1968. Las especies del género Pseudoctenis en la flora triásica de Barreal (San Juan). Ameghiniana 5 (10): 433-446.

Bonetti, M.I.R. 1972. Las "Bennettitales" de la flora Triásica de Barreal (San Juan). Revista del Museo Argentino de Ciencias Naturales Bernardino Rivadavia 1 (10): 307-322.

Borrello, A.V.; Cuerda, A.J. 1965. Grupo Rincón Blanco (Triásico San Juan). Comisión de Investigaciones Científicas, provincia Buenos Aires, Notas 2 (10): 3-20.

Cantrill, D.J. 1995. The occurrence of the fern Hausmannia Dunker (Dipteridaceae) in the Cretaceous of Alexander Island, Antarctica. Alcheringa 19 (3): 243-254.

Charrier, R. 1979. El Triásico de Chile y regiones adyacentes de Argentina. Una reconstrucción paleogeográfica y paleoclimática. Universidad de Chile, Departamento de Geología, Comunicaciones 26: 1-37. Santiago.

Cohen, K.M.; Finney, S.C.; Gibbard, P.L.; Fan, J.-X. (2013; updated). The ICS International Chronostratigraphic Chart v2017/02. Episodes 36: 199-204.

Criado Roque, P. 1979. Subcuenca de Alvear (provincia de Mendoza). In Simposio de Geología Regional Argentina, No. 2 (Turner, J.; editor). Academia Nacional de Ciencias: 811-836. Córdoba.

Damborenea, S.E. 1974. Geología del Cerro Colorado del Cementerio, Barreal, provincia de San Juan (República
Argentina). Revista de la Asociación Geológica Argentina 29 (2): 249-263.

Damborenea, S.E.; Stipanicic, P.N. 2002. Porfido Cuarcífero (Capas con...). In Léxico Estratigráfico de la Argentina. Triásico 8 (Stipanicic, P.N.; Marsicano, C.A.; editors). Asociación Geológica Argentina Serie "B” (Didáctica y Complementaria): 217 p. Buenos Aires.

Drovandi, J.M.; Colombi, C.E.; Bodnar, J.; Ejarque, Y.; García, G.; Santi Malnis, P.; Morel. E.; Alcober, O. 2016. Evidencias preliminares de un bosque destruido por un evento volcaniclástico en el Triásico de Formación El Alcázar, Cuenca Cuyana, San Juan, Argentina. Jornadas de Geología de Precordillera, No. 3. Acta Geológica Lilloana 28 Suplemento: 94-100.

Du Toit, A.L. 1927a. A geological comparison of South America with South Africa. Carnegie Institution, Publication 381: 1-150.

Du Toit, A.L. 1927b. The fossil flora of the Upper Karroo Beds. Annals of the South African Museum 12 (2): 289-418.

Frenguelli, J. 1944. Las especies del género Zuberia en la Argentina. Anales del Museo de La Plata. Paleontología, sección B; Paleobotánica 1: 1-30.

Frenguelli, J. 1948. Estratigrafía y edad del llamado Rético en la Argentina. Anales de la Sociedad Argentina de Estudios Geográficos, GAEA 8: 159-309.

Ganuza, D.G.; Zamuner, A.B.; Artabe, A.E.; Spalletti, L.A. 1998. Sistemática y Paleoecología de la Flora Triásica de Hilario-Agua de Los Pajaritos (Formación El Alcázar), Provincia de San Juan, Argentina. Ameghiniana 35 (3): 271-283.

Groeber, P.; Stipanicic, P.N. 1953. Triásico. In Mesozoico (Groeber, P.; Stipanicic, P.N.; Mingramm, A.R.G.; editores). Geografía de la República Argentina, Sociedad Argentina de Estudios Geográficos GAEA 2: 13-131. Buenos Aires.

Hammer, O.; Harper, D.A.T.; Ryan, P.D. 2001. PAST: Paleontological Statistic software package for education and data analysis. Paleontologia Eletronica 4 (1): 1-9.

Heim, A. 1945. Observaciones tectónicas en Barreal, Precordillera de San Juan. Revista del Museo de La Plata (n.s.), Geología 2 (16): 267-286.

Herbst, R. 1995. Millerocaulis stipabonettii nov. sp. (Osmundaceae, Filices) from the Late Traissic Cepeda Formation of San Juan Province, Argentina. Mededelingen Rijks Geologische Dienst 53: 13-19.

Hidalgo, N.; Senese, A.; Cano, E.; Sarquís, P. 2016. Caracterización y evaluación de la calidad de bentonitas 
provenientes de las provincias de San Juan y Río Negro (Argentina) para uso en industria petrolera y cerámica. Boletín Geológico y Minero 127 (4): 791-806.

Kokogian, D.A.; Mancilla, O. 1989. Análisis estratigráfico secuencial de la Cuenca Cuyana. In Cuencas Sedimentarias Argentinas (Chebli, G.A.; Spalletti, L.A.; editores). Universidad Nacional de Tucumán, Serie Correlación Geológica 6: 169-201. San Miguel de Tucumán.

Kokogian, D.; Boggetti, D.; Rebay, G. 1988. Cuenca Cuyana. El análisis estratigráfico secuencial en la identificación de entrampamientos sutiles. In Congreso Nacional Exploración de Hidrocarburos, No. 1, Actas 2: 649-674. Buenos Aires.

Kokogian, D.; Fernández Seveso, E.; Mosquera, A. 1993. Las secuencias sedimentarias triásicas. In Congreso Geológico Argentino, No. 12 y Congreso de Exploración de Hidrocarburos, No. 2. Relatorio Geología y Recursos Naturales de Mendoza 1 (7): 65-78. Buenos Aires.

Kokogian, D.A.; Spalletti, L.A.; Morel, E.; Artabe, A.E.; Martínez, R.N.; Alcober, O.A.; Milana, J.P.; Zavattieri, A.M.; Papú, O.H. 1999. Los depósitos continentales triásicos. In Geología Regional Argentina (Caminos, R.; editor). Secretaría de Estado de Minería de la Nación: 377-398. Buenos Aires.

Kokogian, D.A.; Spalletti, L.A.; Morel, E.M.; Artabe, A.E., Martínez, R.N.; Alcober, O.A.; Milana, J.P.; Zavattieri, A.M. 2001. Estratigrafía del Triásico argentino. In El Sistema Triásico de Argentina (Artabe, A.E.; Morel, E.M.; Zamuner, A.B.; editores). Fundación Museo de La Plata "Francisco Pascasio Moreno": 25-54. La Plata.

Legarreta, L.; Kokogian, D.A.; Dellape, D. 1992: Estructuración terciaria de la Cuenca Cuyana: ¿Cuánto de inversión tectónica? Revista de la Asociación Geológica Argentina 47 (1): 83-86.

Llambías, E.; Sato, A. 1990. El Batolito de Colangüil (29-31 $\left.{ }^{\circ} \mathrm{S}\right)$ Cordillera Frontal de Argentina: estructura y marco tectónico. Revista Geológica de Chile 17 (1): 89-108.

Llambías, E.; Sato, A. 1995. Tectónica y magmatismo en el límite Pérmico-Triásico de la Cordillera Frontal. In Reunión del Triásico del Cono Sur, No. 2, Actas: 22-26. Bahía Blanca.

López Gamundí, O. 1994. Facies distribution in an asymmetric half-graben: the northern Cuyo Basin (Triassic), western Argentina. In International Sedimentological Congress, No. 14, Abstracts: 6-7. Recife.

López Gamundí, O.; Martínez, M. 2003. Esquema estratigráfico-secuencial para las unidades neopaleozoicas de la cuenca Calingasta-Uspallata en el flanco occidental de la Precordillera. Revista de la Asociación Geológica Argentina 58 (3): 367-382.

Lutz, A.I.; Herbst, R. 1992. Una nueva especie de Rhexoxylon del Triásico de Barreal, San Juan Argentina. Asociación Paleontológica Argentina, Publicación Especial 2: 73-76.

Mack, G.H.; James, W.C.; Monger, H.C. 1993. Classification of paleosols. Bulletin of the Geological Society of America 105 (2): 129-136.

Marsicano, C.; Barredo, S.P. 2004. A Triassic tetrapod footprint assemblage from southern South America: palaeobiogeographical and evolutionary implications. Paleogeography, Paleoclimatology, Paleoecology 203: 313-335.

Menéndez, C.A. 1956. Protophyllocladoxylon cortaderitaensis sp. nov. Tronco fósil del Triásico de Barreal (provincia de San Juan). Revista de la Asociación Geológica Argentina 11 (4): 273-280.

Mésigos, M.G. 1953. El Paleozoico Superior de Barreal y su continuación austral, Sierra de Barreal, Provincia de San Juan. Revista de la Asociación Geológica Argentina 8 (2): 65-109.

Miall, A.D. 1978: Lithofacies types and vertical profile models in braided rivers: a summary. In Fluvial Sedimentology (Miall, A.D.; editor). Canadian Society of Petroleum Geology, Memoir 5: 597-604.

Miall, A.D. 1996. The Geology of Fluvial Deposits. Sedimentary Facies, Basin Analysis, and Petroleum Geology. Springer: 582 p. New York.

Morel, E.M.; Artabe, A.E.; Zavattieri, A.M.; Bonaparte, J. 2001. Cronología del Triásico de Argentina. In El Sistema Triásico de Argentina (Artabe, A.E.; Morel, E.M.; Zamuner, A.B.; editores). Fundación Museo de La Plata "Francisco Pascasio Moreno": 227-253. La Plata.

Morel, E.M.; Artabe, A.E.; Spalletti, L.A. 2003. The Triassic floras of Argentina: Biostratigraphy, Floristic events and comparison with other areas of Gondwana and Laurasia. Alcheringa 27 (3): 231-243.

Ottone, E.G. 2006. Plantas triásicas del Grupo Rincón Blanco, provincia de San Juan, Argentina. Ameghiniana 43 (2): 477-486.

Ottone, E.G.; Rodríguez Amenábar, C. 2001. A new disaccate pollen grain from the Triassic of Argentina. Ameghiniana 38 (2): 157-161.

Quartino, B.J.; Zardini, R.A.; Amos, A.J. 1971. Estudio y exploración geológica de la región de Barreal-Calingasta. Provincia de San Juan, República Argentina. Asociación Geológica Argentina, Monografía 1: 1-184.

Ramos, V.; Kay, S. 1991. Triassic rifting and associated basalts in the Cuyo basin, central Argentina. In Andean Magmatism and its Tectonic Setting (Harmon, R.S.; 
Rapela, C.W.; editors). Geological Society of America, Special Paper 265: 79-91. Boulder.

Retallack, G.J. 1988. Field recognition of paleosols. In Paleosols and Weathering Through Geologic Time: PrincipIes and Applications (Reinhardt, J.; Sigles, W.R.; editors). Geological Society of America, Special Paper 216: 1-20.

Rincón, M.F.; Barredo, S.P.; Zunino, J.; Salinas, A.; Reinante, S.M.E.; Manoni, R. 2011. Síntesis general de los bolsones intermontanos de San Juan y La Rioja. In Cuencas Sedimentarias Argentinas. Congreso de Exploración y Desarrollo de Hidrocarburos, No. 13 (Kowlowsky, E.; Legarreta, L.; Boll, A.; editors). Instituto Argentino del Petróleo y el Gas: 321-406. Mar del Plata.

Rocher, S.; Abarzúa, F.; Tapia Baldis, C.; López, G. 2016. Volcanism of the Triassic cuyo basin in the CalingastaBarreal Valley, western Argentina. In Jornadas de Geología de Precordillera, No. 3, Acta Geológica Lilliana 28 (Suplemento): 163-169.Tucumán.

Rodríguez Amenábar, C.; Ottone, E.G. 2003. La aplicación de Botryococcus (Chlorococcales) como indicador paleoambiental en el Triásico de Argentina. Revista Española de Micropaleontología 35 (2): 25-35.

Rolleri, E.O.; Criado Roque, P. 1968. La cuenca triásica del norte de Mendoza. In Jornadas Geológicas Argentinas, No. 3, Actas 1: 1-76. Comodoro Rivadavia.

Rolleri, E.O.; Fernández Garrasino, C. 1979. Comarca septentrional de Mendoza. In Simposio de Geología Regional Argentina, No. 2 (Turner, J.C.M.; editor). Academia Nacional de Ciencias I: 771-809. Córdoba.

Rossa, N.; Mendoza, M. 1999. Manifestaciones volcánicas en la cuenca triásica de Barreal Calingasta, San Juan. In Congreso Geológico Argentino, No. 14, Actas 2: 171-174. Salta.

Ruiz, D.P.; Bodnar, J. 2019. The oldest record of Juniperoxylon, a cupressaceous fossil wood from the Middle Triassic of Argentina. Acta Palaeontologica Polonica 64 (3): 481-488.

Soil Survey Staff. 1999. Soil Taxonomy: A Basic System of Soil Classification for Making and Interpreting Soil Surveys. Agriculture Handbook 436. Natural Resources Conservation Service: 869 p. Washington DC.

Spalletti, L.A. 1999. Cuencas triásicas del oeste Argentino: origen y evolución. Acta Geológica Hispánica 32 (1-2): 29-50.

Spalletti, L.A. 2001a. Evolución de las cuencas sedimentarias. In El Sistema Triásico de Argentina (Artabe, A.E.; Morel, E.M.; Zamuner, A.B.; editores). Fundación Museo de La Plata "Francisco Pascasio Moreno": 81-101. La Plata.
Spalletti, L.A. 2001b. Modelo de sedimentación fluvial y lacustre en el margen pasivo de un hemigraben: el Triásico de la Precordillera occidental de San Juan, República Argentina. Revista de la Asociación Geológica Argentina 56 (2): 189-210.

Spalletti, L.A.; Barrio, C.A. 1998. Arquitectura y Secuencias de los sistemas fluviales triásicos (Formación Río Blanco) en la Cuenca Cuyana, Argentina. Revista de la Asociación Geológica Argentina 53 (3): 388-400.

Spalletti, L.A.; Artabe, A.E.; Morel, E.M.; Brea, M. 1999. Biozonación paleoflorística y cronoestratigrafía del Triásico Argentino. Ameghiniana 36 (4): 419-451.

Stappenbeck, R. 1910. La Precordillera de San Juan y Mendoza. Anales del Ministerio de Agricultura de la Nación, Sección Geología, Mineralogía y Minería 4: 3-187.

Stipanicic, P.N. 1947. Estudio geológico, estratigráfico y tectónico de la Precordillera, al este del río de Los Patos en Sorocayense (San Juan). Tesis Doctoral (Unpublished), Universidad de Buenos Aires: 270 p. Stipanicic, P.N. 1957. El Sistema Triásico en la Argentina. In Congreso Geológico Internacional,No. 20, Sección II: El Mesozoico en el Hemisferio Occidental y sus correlaciones mundiales: 77-112. Mexico.

Stipanicic, P.N. 1972. Cuenca triásica de Barreal. In Geología Regional Argentina (Leanza, A.F.; editor). Academia Nacional de Ciencias: 537-566. Córdoba. Stipanicic, P.N. 1979. El Triásico del valle del Río de Los Patos (provincia de San Juan). In Geología Regional Argentina (Turner, J.C.M.; editor). Academia Nacional de Ciencias: 695-744. Córdoba.

Stipanicic, P.N. 1983. The Triassic of Argentina and Chile. In The Phanerozoic geology of the World II, The Mesozoic (Moullade, M.; Nairim, A.E.M.; editors). Elsevier: 181-199. Amsterdam

Stipanicic, P.N. 2001. Antecedentes geológicos y paleontológicos. In El Sistema Triásico de Argentina (Artabe, A.E.; Morel, E.M.; Zamuner, A.B.; editores). Fundación Museo de La Plata "Francisco Pascasio Moreno": 1-21. La Plata.

Stipanicic, P.N. 2002a. El Triásico en la Argentina. In Léxico Estratigráfico de La Argentina. Triásico 8 (Stipanicic, P.N.; Marsicano, C.A.; editors). Asociación Geológica Argentina Serie "B" (Didáctica y Complementaria): 1-24. Buenos Aires.

Stipanicic, P.N. 2002b. Cortaderita (Formación...), Nota 1 y 2. In Léxico Estratigráfico de La Argentina. Triásico 8 (Stipanicic, P.N.; Marsicano, C.A.; editores). Asociación Geológica Argentina Serie "B” (Didáctica y Complementaria): 106. Buenos Aires. 
Stipanicic, P.N.; Menéndez, C.A. 1949. Contribución al conocimiento de la flora fósil de Barreal (provincia de San Juan). I. Dipteridaceae. Boletín de Informaciones Petroleras 24: 44-73. Buenos Aires.

Stipanicic, P.N.; Spalletti, L.A. 2002a. Barreal (Formación...). In Léxico Estratigráfico de La Argentina. Triásico 8 (Stipanicic, P.N.; Marsicano, C.A.; editores). Asociación Geológica Argentina Serie "B" (Didáctica y Complementaria): 43-44. Buenos Aires.

Stipanicic, P.N.; Spalletti, L.A. 2002b. Cepeda (Formación...). In Léxico Estratigráfico de La Argentina. Triásico 8 (Stipanicic, P.N.; Marsicano, C.A.; editores). Asociación Geológica Argentina Serie "B” (Didáctica y Complementaria): 63-64. Buenos Aires.

Stockey, R.A.; Rothwell, G.W.; Little S.A. 2006. Relationships among fossil and living dipteridaceae: anatomically preserved Hausmannia from the Lower Cretaceous of Vancouver Island. International Journal of Plant Sciences 167 (3): 649-663.

Strelkov, E.; Álvarez, L. 1984. Análisis estratigráfico y evolutivo de la cuenca triásica mendocina-sanjuanina. In Congreso Geológico Argentino, No. 9, Actas 3: 115-130. San Carlos de Bariloche.

Tabor, N.J.; Montañez, I.P.; Scotese, C.R.; Poulsen, C.J.; Mack, G.H.; Fielding, C.R.; Isbell, J.L. 2008. Paleosol archives of environmental and climatic history in paleotropical western Pangea during the latest Pennsylvanian through Early Permian. Resolving the late Paleozoic ice age in time and space: Geological Society of America, Special Paper 441: 291-303.

Tabor, N.J.; Myers, T.S. 2015. Paleosols as indicators of paleoenvironment and paleoclimate. Annual Review of Earth and Planetary Sciences 43: 333-361.

Tapia Baldis, C. 2013. Caracterización litofacial y petrográfica de los depósitos piroclásticos aflorantes en la Sierra de Barreal y su posible vinculación al Grupo Choiyoi (Permotriásico). Trabajo final de licenciatura (Unpublished), Universidad Nacional de San Juan, Facultad de Ciencias Exactas, Físicas y Naturales: 121 p.
Terruggi, M.E. 1971. Criterios para el reconocimiento y estudio de los paleosuelos. Revista de la Asociación Geológica Argentina 26 (4): 485-490.

Treo, C.H.; Baraldo, J.A.; Merino, A.M. 1985. Estratigrafía y estructura del Triásico de la zona El Alcázar-Colón, Departamento Calingasta. In Jornadas de Geología de la Precordillera, No. 1, Actas 1: 59-64. San Juan.

Uliana, M.A.; Biddle, K.T.; Cerdan, J. 1989. Mesozoic extension and the formation of Argentine sedimentary basins. In Extensional Tectonics and Stratigraphy of the North Atlanctic Margins (Tankard, A.; Balkwill, H.; editors). American Association of Petroleum Geologists, Memoir 46: 599-613.

Van Konijenburg-van Cittert, J.H.A. 2002. Ecology of some Jurassic ferns in Eurasia. Review of Palaeobotany and Palynology 199: 113-124.

Yrigoyen, M.R.; Stover, L.E. 1970. La palinología como elemento de correlación del Triásico en la Cuenca Cuyana. In Jornadas Geológicas Argentinas, No. 4, Actas 2: 427-447. Mendoza.

Zamora Valcarce, G.; Cervera, M.; Bernardo, L.M.; Barredo, S. 2008. Geología y potencial petrolero de un bolsón intermontano: Bloque Tamberías, provincia de San Juan. Petrotecnia 49 (6): 52-62.

Zamuner, A.B.; Artabe, A.E.; Ganuza, D.G. 1999. A new Peltasperm (Gymnospermopsida) from the Middle Triassic of Argentina. Alcheringa 23 (3): 185-191.

Zamuner, A.B.; Zavattieri, A.M.; Artabe, A.E.; Morel, E.M. 2001. Paleobotánica. In El Sistema Triásico de Argentina (Artabe, A.E.; Morel, E.M.; Zamuner, A.B.; editors). Fundación Museo de La Plata "Francisco Pascasio Moreno": 143-184. La Plata.

Zerfass, H.; Chemale, F.; Schultz, C.L.; Lavina, E. 2004. Tectonics and sedimentation in Southern South America during Triassic. Sedimentary Geology 166 (3-4): 265-292.

Zöllner, W. 1950. Observaciones tectónicas en la Precordillera Sanjuanina, zona de Barreal. Revista de la Asociación Geológica Argentina 5 (3): 111-126.

Manuscript received: November 30, 2017; revised/accepted: October 30, 2018; available online: February 04, 2019. 